Document downloaded from:

http://hdl.handle.net/10251/83435

This paper must be cited as:

Climent Olmedo, MJ.; Corma Canós, A.; Iborra Chornet, S.; Martí Montaner, L. (2016). Use of mesoporous molecular sieves in the production of fine chemicals: Preparation of dihydroquinolinones of pharmaceutical interest from $2 i$-aminochalcones. ChemCatChem. 8(7):1335-1345. doi:10.1002/cctc.201501403.

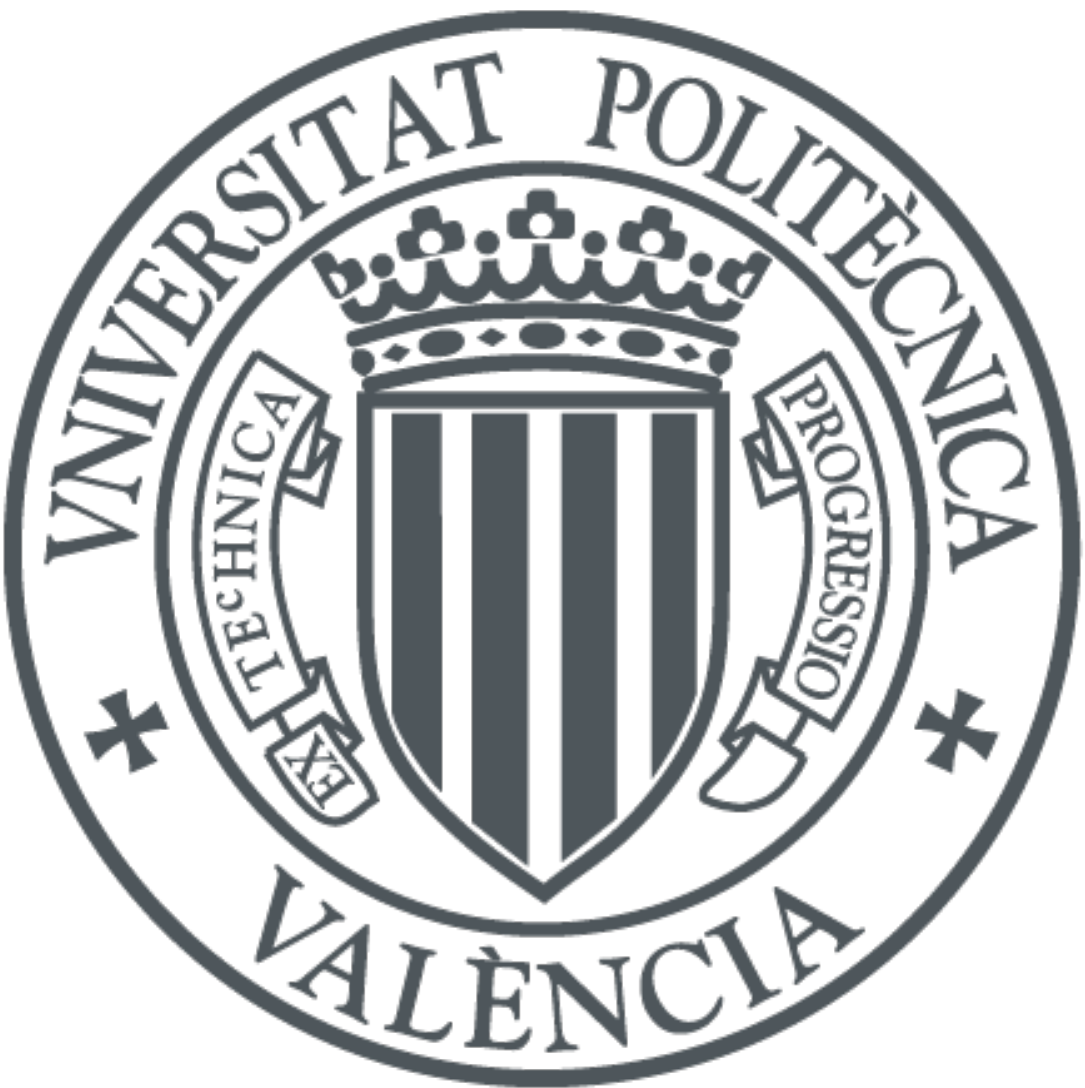

The final publication is available at

http://doi.org/10.1002/cctc.201501403

Copyright Wiley

Additional Information 


\title{
Use of mesoporous molecular sieves in the production of fine chemicals: \\ Preparation of dihydroquinolinones of pharmaceutical interest from 2'- aminochalcones
}

\author{
María J. Climent*, A. Corma*, S. Iborra, L. Martí \\ Instituto de Tecnología Química (UPV-CSIC) \\ Universitat Politécnica de València \\ Avda dels Tarongers s/n, 46022, Valencia (Spain) \\ Fax: (+34) 963877809 \\ E-mail: acorma@itq.upv.es \\ mjcliol@qim.upv.es
}

\begin{abstract}
Solid catalysts can be an alternative to homogeneous mineral Bronsted and Lewis acids for the synthesis of pharmaceuticals provided that diffusional and adsorption properties of reactants and products could be controlled. Structured micro and especially monolayered zeolites and mesoporous material can be active and selective for performing intramolecular cyclization reaction, and more specifically for intramolecular aza-Michael cyclizations of 2'-aminochalcones to yield aryl-2,3-dihydro-4(1H)-quinolinones of pharmaceutical interest. However, the catalyst deactivates by strong adsorption of the basic quinolinone product. Product desorption has been controlled by optimizing catalyst pore structure and surface composition, together with a proper selection of solvent and reaction temperature.

Process intensification for the synthesis of aryl-2,3-4(1H)-quinolinones of pharmaceutical interest has been achieved by preparing catalysts that allow the one pot synthesis of the dihydroquinolinones starting from 2'-nitrochalcones with excellent yields.
\end{abstract}

Keywords: ITQ-2 zeolite, MCM-41, fine chemicals, one pot process, dihydroquinolinones, 2'-aminochalcones 


\section{Introduction}

2-Aryl-2,3-dihydro-4(1H)-quinolinones ～(or 2-aryl-1,2,3,4-tetrahydro-4quinolones) derivatives are six-membered nitrogen heterocyclic compounds considered as aza-analogues of flavanones. The synthesis of these compounds has generated continuous interest because of their wide range of biological activities, such as hypertensive, antibacterial, anti-inflammatory and as anticancer and immunosuppressive agent. ${ }^{[1-3]}$ They display significant cytotoxicity against a panel of human tumour cell lines and also have high activity toward multi-drug resistant $\mathrm{KB}-\mathrm{VIN}$, and ovarian $1 \mathrm{~A} 9$ cell lines. Besides, aza-analogues of flavanones can also serve as valuable precursors for the synthesis of other pharmaceutical and active compounds; ${ }^{[4,5]}$ with potent antimitotic antitumor effects, ${ }^{[6]}$ such as 2 -aryl-4-quinolones derivatives ${ }^{[7]}$ and 4alcoxy-2-arylquinolines, ${ }^{[8]}$ which are often not readily accessible by other routes. ${ }^{[9,10]}$

The synthesis of 2,3 -dihydro- $4(1 \mathrm{H})$-quinolinones is generally accomplished by the base or acid catalysed intramolecular aza-Michael cyclization of substituted 2 '-aminochalcones, through the nucleophilic attack of the amino group on the $\beta$ carbon of the enone function, which leads to the formation of six-membered heterocyclic systems (6-endo-trig cyclization product) as predicted from Baldwin's rules (Scheme 1). ${ }^{[1]}$ Base homogeneous catalysts such as piperidine, $\mathrm{KOH},{ }^{[12]}$ L-Proline, ${ }^{[13]}$ as well as Bronsted and Lewis acids such as orthophosphoric in acetic acid, ${ }^{[7]}$ PEG-400, ${ }^{[14]}$ wet cyanuric chloride, ${ }^{[15]}$ zinc chloride, ${ }^{[16]}$ Ytterbium(III) triflate $\left(\mathrm{YbOTf}_{3}\right.$ in ionic liquid $\left([\mathrm{bmim}] \mathrm{BF}_{4}\right)^{[17]}$ or lithium tetrafluoroborate ${ }^{[18]}$ have been used as catalysts for the cyclization of $2^{\prime}-$ 
aminochalcones into quinolinones. However, many of these homogeneous processes involve the use of corrosive reagents, require large amount of catalyst, long reaction times, and high temperatures, giving in most cases, low yields of products. This is due to the fact that strong bases and also acids promote polymerization reactions, while generating considerable amount of wastes. To overcome these drawbacks, different heterogeneous Brönsted and Lewis acid catalysts such as silica supported phosphomolybdic acid (PMA$\left.\mathrm{SiO}_{2}\right),{ }^{[19]}$ silica supported $\mathrm{TaBr}_{5},{ }^{[20]}$ silica supported $\mathrm{NaHSO}_{4},{ }^{\left[{ }^{[1]}\right.}$ alumina supported $\mathrm{CeCl}_{3} \cdot 7 \mathrm{H}_{2} \mathrm{O}-\mathrm{Nal},{ }^{[22]}$ and Montmorillonite $\mathrm{K}-10$ clay under microwave irradiation $^{[23]}$ have been proposed to promote the intramolecular aza-Michael cyclization of 2'-aminochalcones. In Table 1 the reaction conditions and yields reported in the literature using the above catalytic systems have been summarized.

As can be observed there the heterogeneous catalytic systems reported present several limitations such as the use of large catalyst to substrate ratios (from 1.35 to $130.15 \mathrm{~g}$ catalyst per g of 2'-aminochalcone), in some cases long reaction times and temperatures higher than $100{ }^{\circ} \mathrm{C}$ or microwave activation are required. Additionally, in the case of acid supported catalysts, leaching of the acid into the reaction media could be expected, which may limit recovery and recyclability of the catalyst. Therefore the development of efficient and stable heterogeneous catalysts for the aza-Michael addition is desirable.

Cascade processes involving multiple catalytic events is an important area of research in organic chemistry since it can help to decrease raw materials consumption and energy, producing lower amount of wastes. ${ }^{[24,25]}$ In this sense, we have recently presented an efficient method to synthesize a variety of 2 - 
aminochalcones through a cascade process which involves, as the first step, the Claisen-Schmidt condensation of o-nitroacetophenones and benzaldehyde derivatives followed by reduction of the nitro into the corresponding amino group. ${ }^{[26]}$ It would then be of much interest to develop a single cascade process able to directly produce dihydroquinolinones from nitrochalcones. In the first part of this work, we will show that this can be achieved by means of a catalyst based on micro and mesoporous molecular sieves. Thus, we will present how a catalyst could be optimized for maximizing yield and catalyst life during the synthesis of a variety of dihydroquinolinones of pharmaceutical interest, starting from the substituted 2'-aminochalcones, with excellent activities and selectivities. Then, in the second part of this work, a cascade process will be presented in where hydrogenation of 2 '-nitrochalcones into aminochalcones will be coupled with their cyclization for obtaining dihydroquinolinones with a bifunctional metal-acid catalyst.

\section{Results and Discussion}

\section{Influence of catalyst structure}

As stated above, the most common method to obtain 2-phenyl-2,3dihydroquinolin-4(1H)-one (2) from 1-(2-aminophenyl)-3-phenylprop-2-en-1-one (2'-aminochalcone, $\mathbf{1})$ is by means of the acid catalyzed aza-Michael intramolecular addition (Scheme 1).

The general mechanism for the intramolecular cyclization of 2'-aminochalcone in acidic media involves the protonation, or Lewis acid interaction, of the oxygen of the enone group. This produces the activation of the $\beta$-carbon towards the nucleophilic attack of the amino group, leading to the formation of six- 
membered heterocyclic systems, in this case dihydroquinolinone (6-endo-trig cyclization product) (Scheme 2). The mechanism is in good agreement with theoretical studies recently presented by Reyes et al., ${ }^{[27]}$ who have shown that the electrophilic character of the $\beta$-carbon in 2'-aminochalcones increases $18 \%$ in acidic media (TFA acid).

Among the different potential solid acid catalysts able to perform aza-Michael reaction, we thought that Bronsted or Lewis acid aluminosilicates could be the most promising catalysts since they can offer much flexibility for catalyst design. They can range from amorphous to crystalline micro to mesoporous structures that can be synthesized with different pore sizes, acidity and hydrophobichydrophilic properties. ${ }^{[28]}$ Moreover, the thermal stability of aluminosilicates allows its regeneration by a simple calcination in air.

For the study of the ring closure process, the trans-2'-aminochalcone was selected as substrate model and different structured acidic solid catalysts with different pore topologies and dimensions were chosen. We started with large pore microporous zeolites though, we were expecting reactant and product diffusional problems, as well as, a strong adsorption of the slightly basic products within the micropores of the zeolites. Then we have also introduced in our catalytic study a 2D zeolite (ITQ-2) and a mesoporous structured material (MCM-41) that should be less or not limited by reactants and products diffusion. More specifically, we have studied the potential of a USY tridirectional 12 ring (12R) zeolite with cavities, a tridirectional 12R zeolite without cavities (HBeta), a 12R unidirectional zeolite (Mordenite), a delaminated zeolite (ITQ-2) and a structured mesoporous aluminosilicate (MCM-41), all of them bearing Bronsted acid sites. Meanwhile, and since this type of reaction can also be catalyzed by 
Lewis sites, metal framework substituted Sn-Beta and Zr-Beta zeolites and SnMCM-41, were tested in the cyclization of trans-2'-aminochalcone. As a reference homogeneous Bronsted acid, we have chosen p-toluenesulfonic acid $(p-T S A)$ and a mixture of acetic and orthophosphoric acid.

A blank experiment in absence of catalyst was performed and $5 \%$ conversion was observed after 8h. The chemical composition, textural properties and acidity of the solid catalyst studied are given in Table 2, and its preparation is presented in the experimental section.

Firstly the $12 \mathrm{R}$ unidirectional zeolite (Mordenite) and two zeolites with tridimensional pore topology and strong Brönsted acidity (HBeta and USY) were selected for performing the desired cyclization. When the cyclization reaction was carried out over these catalysts at $100{ }^{\circ} \mathrm{C}$ using toluene as a solvent, Mordenite exhibited similar turnover frequency (TOF) than Beta zeolite but a higher deactivation rate could be deduced from the results in Figure 1. Indeed it can be seen that the conversion curve for Mordenite stops rapidly with reaction time, at still low levels of conversion (see Table 3 entries 1 and 2). This fast deactivation of the Mordenite can be attributed to the unidirectionality of the pores that can be easily plugged by strongly adsorbed reactant and product. Better catalytic activity and yield were achieved with the tridirectional USY zeolite (Table 3, entry 4), being the TOF about 6 times higher than in the case of Beta zeolite, with smaller pore diameter. These results indicate that the pore dimensions and topology, and therefore reactant diffusion and site accessibility play an important role on the catalytic behavior of the microporous materials. Pore dimensions and topology result in smaller geometrical restrictions for the diffusion of reactant and/or product in USY compared with HBeta zeolite. In fact, 
if one considers the molecular dimensions of the trans-2'-aminochalcone $(0.78$ $\times 0.74 \times 0.64 \mathrm{~nm})$ and dihydroquinolinone $(1.07 \times 0.59 \times 0.55 \mathrm{~nm})$ it appears that the molecular size of the trans-2'-aminochalcone is in the range of the pore sizes of USY zeolite $(0.74 \times 0.74 \mathrm{~nm})$ and some larger than the pore diameter of HBeta $(0.75 \times 0.57$ and $0.56 \times 0.56 \mathrm{~nm})$ and Mordenite $(0.70 \times 0.65$ and $0.57 \times$ $0.26 \mathrm{~nm}$ ). Consequently, geometrical restrictions for reactant diffusion, could be expected on the three catalysts increasing in the order USY $<$ HBeta< Mordenite. In order to check this point, a nanocrystalline Beta zeolite sample with smaller crystal size (10-20nm) (Betanano), was prepared and tested in the cyclization reaction. As can be seen in Figure 2 when the zeolite crystallite size becomes smaller and consequently the ratio of the external to the internal surface area increases, the initial reaction rate considerably increases, achieving a $92 \%$ yield of dihydroquinolinone after $6 \mathrm{~h}$ with the nanocrystalline Beta zeolite (Table 3, entry 3). These results confirm diffusional restrictions for reactant and product in our reaction, also in a tridirectional zeolite such as Beta. Although a batch reactor is not the best-suited reactor to study catalyst deactivation, looking at the shape of the curves in Figure 1 it can already be inferred that an important deactivation of the catalysts is occurring during the reaction. Indeed, with the microporous 3D zeolites, conversion practically stops at low conversions and, in a fist approximation, it could be said that the order of catalyst deactivation are Mordenite $>$ Beta $>$ USY .

The deactivation of the catalysts can be probably due to the fact that both 2'aminochalcone and dihydroquinolinone have a weakly basic character, which favours their strong adsorption, blocking the pores and/or acid sites. As can be seen in Figure 1, catalyst deactivation appears to be more important on HBeta 
than on USY and, in fact, the thermogravimetric analysis of the used catalysts, showed that while on USY zeolite $17 \mathrm{wt} \%$ (with respect to the catalyst) of organic material remains on the catalyst after their use, on the Beta zeolite the organic material was twofold higher (38 wt\%). Moreover analysis of the molecules remaining adsorbed on the catalyst after reaction (see Table 4), indicates that most of the organic adsorbed corresponds to the reaction product i.e., dihydroquinolinone.

Thus, tridirectional HBeta and USY zeolites appear not suitable catalysts to carry out the aza-Michael intramolecular cyclization due to the existence of restricted diffusion and enhanced adsorption of the reactant and product in the pores, leading to a fast deactivation of the catalyst.

From all the above results, it can be inferred that solid catalysts with larger pores and milder acidities should be more adequate for performing the azaMichael intramolecular cyclization of the trans-2'-aminochalcone. Thus, a delaminated zeolite with large external surface area, low micropore volume and medium-strong acidity (ITQ-2) was selected to perform the cyclization of the trans-2'-aminochalcone. This zeolite was prepared by delamination of a layered MWW precursor, ${ }^{[29]}$ resulting in thin zeolite sheets $(2.5 \mathrm{~nm}$ thick) with a hexagonal array of cups with an aperture of $0.7 \mathrm{~nm}$.

When the reaction was performed in the presence of the delaminated zeolite ITQ-2(Si/Al=12), an important increase in the conversion of trans-2'aminochalcone with respect to the tridirectional zeolites was observed (see Figure 1 and Table 3, entries 5, 2 and 4). This behaviour should be attributed to the decrease of the diffusional limitations of reactant and product, owing to the much larger external surface of ITQ-2. Nevertheless, from the shape of the 
conversion versus time curve for ITQ-2, it can be inferred that the catalyst also deactivates with time (see Figure 1). The cause of the deactivation was studied by stopping the reaction after 6 hours when the maximum yield of dihydroquinolinone (2) was $72 \%$ (with $100 \%$ selectivity). Then, an extraction of the solid catalyst with a Soxhlet apparatus, showed that $34 \mathrm{wt} \%$ (with respect to the amount of catalyst) of organic material remains retained on the catalyst surface. Moreover, when the extracted catalyst was reused in a second cycle, it was observed that the maximum yield of dihydroquinolinone achieved after $6 \mathrm{~h}$ was only $45 \%$. Since in the case of ITQ-2 the diffusion limitations are lesser than with Mordenite, HBeta or USY zeolites, we infer that the deactivation of ITQ-2 zeolite occurs by the adsorption of basic products. Indeed, IR analysis of the delaminated zeolite after being used in the reaction show a band at 1630 $\mathrm{cm}^{-1}$ that can be assigned to the carbonyl group of the dihydroquinolinone (Figure 1 SI).

To decrease the impact on catalyst deactivation by adsorption of the mildly basic reactant and product we thought to use a mesoporous catalyst such as the aluminosilicate MCM-41 with weak acidity and pore diameter of $3.2 \mathrm{~nm}$. It is expected that this catalyst should allow an easier diffusion of reactant and product and a lower irreversible adsorption of the product.

The results presented in Figure 3 indicate that it is possible with the MCM41(15) sample, to achieve a six times larger TOF than with ITQ-2, and a total conversion of trans-2'-aminochalcone of $94 \%$ with $100 \%$ selectivity to dihydroquinolinone (2) (see Table 3). When these results are compared with those previously reported using alumina supported $\mathrm{CeCl}_{3} \cdot 7 \mathrm{H}_{2} \mathrm{O}-\mathrm{Nal},{ }^{[22]}$ it is 
possible to see that similar yields of dihydroquinolinone are achieved (Table 1), however the amount of catalyst required was between 17-30 times larger.

On the other hand, when samples with higher Si/Al ratio were used (entries 7 and 8 , Table 2) the activities were considerably decreased due to the number of Bronsted acid sites associate to Al decrease. These results indicate that a good compromise between number and strength of acid sites exist in the MCM41(15) sample.

When the MCM-41(15) was reused without any previous treatment in a second cycle, only $50 \%$ yield of dihydroquinolinone (2) was obtained after $8 \mathrm{~h}$ reaction time, indicating that an important catalyst deactivation also occurs with MCM41. Since XRD patterns of the fresh and used catalyst showed that the crystallinity of the catalyst was maintained (see Figure 2SI), this deactivation could still be due to the adsorption of the basic reactant and product on the acid sites. In fact, the IR spectrum of the used catalyst shows the adsorption band at $1630 \mathrm{~cm}^{-1}$ which is attributed to the carbonyl group of the dihydroquinolinone (2) (Figure $3 \mathrm{SI}$ ).

The used catalyst was subsequently submitted to extraction with a Soxhlet apparatus, and $9 \mathrm{wt} \%$ of organic (with respect to the amount of the catalyst) was recovered, being this amount much smaller than with the zeolite catalysts. Meanwhile the analysis of the extract showed that the organic material was mainly composed by dihydroquinolinone (2).

A pure silica sample (Si-MCM-41) with a surface area of $1100 \mathrm{~m}^{2} \mathrm{~g}^{-1}$ gave very poor activity (5\% yield after $8 \mathrm{~h})$. This result indicates that weak acid sites such as silanol groups practically do not contribute to the catalytic activity of the AIMCM-41 and that the aza-Michael reaction is mainly catalyzed by the bridging 
hydroxyl groups of the aluminosilicate. Moreover, the thermogravimetic analysis of the used Si-MCM-41 after Soxhlet extraction showed that only $1 \mathrm{wt} \%$ of organic remains adsorbed on the catalyst, which indicates that the amount of organic adsorbed on silanol groups do not contribute significantly to catalyst deactivation by pore blocking.

\section{Catalysis by solid Lewis acid catalysts}

From a mechanistic viewpoint, the success of the acid catalyzed aza-Michael reaction relies on the increase of the electrophilicity of the conjugated alkene by interaction of the carbonyl group with the acid site. The increase in electrophilicity of the conjugated alkene can also be achieved by using a Lewis acid catalyst, as said in the introduction section. It is well accepted that the metal ion from a Lewis acid forms a strongly coordinate bond with the electron withdrawing groups in conjugated alkenes, and thereby increase their electrophilicity to facilitate the addition of nitrogenous nucleophiles ${ }^{[18,30]}$ (see Scheme 2). Taking this into account, we have also studied the catalytic activity of microporous and mesoporous solid catalysts bearing Lewis acid sites. Thus, $\mathrm{Sn}$ and $\mathrm{Zr}$ were incorporated into the framework of MCM-41 (Sn-MCM-41) and Beta zeolite (Sn-Beta and Zr-Beta). In these materials the $\mathrm{Sn}$ and $\mathrm{Zr}$ atoms can act as isolated Lewis acid sites, as has been found to occur in various chemical transformations. ${ }^{[31,32]}$

When the reaction was performed in the presence of the Sn-MCM-41 sample the initial reaction rate was very low achieving only $12 \%$ yield of dihydroquinolinone after $8 \mathrm{~h}$ reaction. Better results were obtained with Sn-Beta (see Table 3, entry 11), although in this case the yield of dihydroquinolinone does not surpass $60 \%$ after $8 \mathrm{~h}$. Similar results were obtained with a $\mathrm{Zr}$-Beta 
catalyst (Table 3, entry 12), indicating the Lewis acid sites associated to $\mathrm{Sn}^{+4}$ or $\mathrm{Zr}^{+4}$, though can perform the aza-Michael addition, present relatively low activity and deactivate rapidly.

For comparison purposes the aza-Michael addition was performed using $p$ toluenesulfonic acid ( $p-T S A)$ as a homogeneous Brönsted acid catalyst under the same reaction conditions. The results obtained show a strong oligomerization of the 2'-aminochalcone, achieving only $4 \%$ of dihydroquinolinone (2) after $4 \mathrm{~h}$ reaction time. Moreover, when the temperature was decreased at $30{ }^{\circ} \mathrm{C}$, only $11 \%$ conversion of 2'-aminochalcone with $50 \%$ selectivity to dihydroquinolinone (2) was obtained, while high molecular weight compounds were detected in the reaction media. These results indicated again that strong Bronsted acid catalysts are not adequate for this reaction and, at least in the case of p-TSA secondary reactions, mainly oligomerization of 2'aminochalcone, is promoted. In fact, when the reaction was performed using as homogeneous acid catalyst a mixture of acetic acid and orthophosforic acid (1:1 $\mathrm{v} / \mathrm{v}), \quad 85 \%$ yield of dihidroquinolinone was obtained after $6 \mathrm{~h}$ reaction time (Table 3, entry 14).

\section{Catalysis by solid bases}

Since it has been reported that homogeneous bases can catalyze the cyclization of 2'-aminochalcones, heterogeneous basic catalysts such as $\mathrm{MgO}$ and $\mathrm{Al} / \mathrm{Mg}$ mixed oxides ${ }^{[33,34]}$ were also tested as they showed high activity for performing the intramolecular Michael addition of 2'-hydroxychalcones into flavanones, ${ }^{[35,36]}$ we have also studied the aza-Michael cyclization of trans2'aminochalcone using a MgO sample with Lewis basic sites and high surface area $\left(660 \mathrm{~m}^{2} / \mathrm{g}\right)$. However, only $5 \%$ conversion of 2 '-aminochalcone was 
obtained after $7 \mathrm{~h}$, being the retro-aldol condensation the predominant process. Similar results were reported by Loh et al. when using a strong basic solid catalyst such as FK-supported alumina (at $70{ }^{\circ} \mathrm{C}$ ) where it was found a complete decomposition of the 2'-aminochalcone. ${ }^{[37]}$

\section{Influence of the solvent}

Up to now we have showed that solid catalysts with weak acidity and good accessibility to the active sites, such as MCM- 41 exhibit the best performance for the cyclization of trans-2'aminochalcone into dihydroquinolinole. However, due to the basicity of the compounds involved in the reaction, an important adsorption of organic material on the catalyst surface still takes place leading to catalysts deactivation. A strategy to overcome the catalyst deactivation problem is to use an adequate solvent that can help to desorb the products from the solid catalyst. Here we have studied one polar protic solvent (ethanol), an aprotic polar solvent (acetonitrile) and an apolar solvent (toluene) at $80^{\circ} \mathrm{C}$. The results given in Figure 4 indicate low reaction rates when the reaction was carried out with ethanol as solvent, while better results were obtained with toluene and, specially, with the polar and aprotic acetonitrile. Nevertheless, when the catalyst was reused the conversion was low indicating that product adsorption was still high under these conditions. Therefore, considering that product adsorption is an exothermic process, one could expect the adsorption equilibrium constant for the product and, consequently, the amount of product adsorbed, to decrease when increasing the reaction temperature. Then, the reaction was also performed at $100{ }^{\circ} \mathrm{C}$ and the results given in Figure 5 clearly show a lower deactivation of the catalyst upon reuse, specially with acetonitrile as solvent, and an smaller amount of product remaining adsorbed after the 
reaction is completed ( $3 \mathrm{wt} \%$ with respect to the catalyst). In any case, catalyst deactivation still occurs and regeneration of the catalyst by calcination was required (Figure 6). However, when the reaction temperature was further increased (at $150^{\circ} \mathrm{C}$ ) similar yields of dihydroquinolinole were achieved with the fresh and used catalyst (see Figure 4SI)

\section{Reaction Kinetics}

Kinetic experiments were conducted at different initial concentrations of 2 aminochalcone in toluene using $\mathrm{MCM}-41(15)$ as catalyst and the initial rates were obtained. The plot of the initial rates versus the initial concentration of 2'aminochalcone (Figure 7) indicates a first order reaction with respect to the concentration of 2 -aminochalcone. Similarly, a first order dependency was also found in the isomerisation of $2^{\prime}$-hydroxychalcone into flavanone using homogeneous ${ }^{[38,39]}$ or heterogeneous catalysts. ${ }^{[40]}$ The influence of the reaction product on the rate of the reaction was studied by measuring the initial reaction rate at $1.20 \mathrm{molL}^{-1}$ concentration of $2^{\prime}$-aminochalcone with no dihydroquinolinone added and in the presence of 0.24 and $0.45 \mathrm{molL}^{-1}$ of dihydroquinolinone. Thus, the initial reaction rates measured were $0.9010^{-3}$ and $0.7110^{-3}$ molmin $^{-1} \mathrm{~g}^{-1}$ respectively. These results clearly show the negative effect of the reaction product on the initial rate of the reaction due to a strong competitive adsorption of the reaction product, in agreement with the IR spectra of the used catalyst (Figure 2SI), that showed the adsorption of the dihydroquinolinone.

linitial reaction rates were also obtained at different temperatures in the 50-100 ${ }^{\circ} \mathrm{C}$ range and the first order kinetic rate constants were calculated. The 
Arrhenius plot of the reaction rate constants is showed in Figure 5SI, and an apparent activation energy of $16 \mathrm{kcal} \mathrm{mol}^{-1}\left(69 \mathrm{KJ} \mathrm{mol}^{-1}\right)$ is obtained for the $2^{\prime}$ aminochalcone cyclization using MCM-41(15) catalyst. It is interesting to notice that a higher activation energy $\left(57 \mathrm{kcal} \mathrm{mol}^{-1}\right)$ was reported for the cyclization of 2 -aminochalcone into dihydroquinolinone in the presence of ionic liquid $\left([\mathrm{bmim}] \mathrm{BF}_{4}\right)$ and $\mathrm{MW}$ irradiation. ${ }^{[41]}$ This difference is probably related with differences on the heat of adsorption of the reactant or the stabilization of the transition state in the two catalytic systems, being the stabilization larger in the solid catalyst.

\section{Scope of the reaction}

Since MCM-41 (15) represents a good compromise between acidity and reactant accessibility, it was selected as catalyst to examine the scope for azaMichael cyclization of various substituted 2'-aminochalcones into dihydroquinolinones with pharmacological interest.

In all cases the usual 6-endo ring closure reaction to give dihydroquinolinones occurs, while no 5-exo cyclocondensation to obtain indolinones was observed, as it was theoretically predicted by Reyes et al. ${ }^{[27]}$

Excellent yields and selectivities (>97\%) were obtained using 2'aminochalcones with electron-withdrawing groups (Table 5, entries 2 and 3) or electron-donating groups (Table 5, entries 4 and 5 ) in the aromatic ring. As shown in Table 5 the activities appear to be influenced by the structure and the electron properties of 2'-aminochalcone derivatives. For instance, when electron-donating groups are present in the benzaldehyde derivative moiety, the corresponding cyclic products were obtained with excellent yields in short times, 
whereas with electron-withdrawing substituents longer reaction times were required to achieve high yields. The selectivity was not affected by the electronic nature of the substituents.

Comparison of the present results with previously reported ones (seeTable 1) in where higher amount of catalyst and temperature or microwave irradiation are required along with poor or null reusability of the catalyst, indicates that mesoporous molecular sieves MCM-41(15) represents a clear alternative for the cyclization of 2'-aminochalcones into dihydroquinolinones owing to the combination of accessibility and mild acidity.

\section{One-pot synthesis of dihydroquinolinones starting from 2 '-nitrochalcones}

Since the synthesis of $2^{\prime}$-aminochalcones by Claisen-Schmidt condensation between o-aminoacetophenones and benzaldehyde derivatives in the presence of strong bases leads in general to low yields of 2'-aminochalcones, due to the fact that amino compounds are prone to oligomerization reactions, ${ }^{[7][42]}$ there is an alternative process to obtain these amino compounds by hydrogenation of the corresponding 2 -nitrochalcones. ${ }^{[26,43]}$ With this in mind, we thought to obtain dihydroquinolinones starting from 2'-nitrochalcones in one pot process in the presence of a bifunctional metal-acid catalyst (Scheme 3). Thus, bifunctional Pt on MCM-41 catalysts with 0.1 wt $\%$ and 0.5 wt \% platinum content were prepared. When 2 '-nitrochalcone $(0.5 \mathrm{mmol})$ was dissolved in toluene $(0.5 \mathrm{~mL})$ and heated at $70{ }^{\circ} \mathrm{C}$ under 9 bar of $\mathrm{H}_{2}$ in the presence of 0.1PtMCM-41(15) (20 mg), only 5\% of $2^{\prime}$-aminochalcone (100\% selectivity) was obtained after $3 \mathrm{~h}$ reaction time. When the amount of Pt was increased to 0.5 wt $\%, 85 \%$ of 2'-nitrochalcone was converted in 3 hours but, unfortunately 
only $3 \%$ yield of the final product dihydroquinolinone (4\% selectivity) was obtained. In this case, the major products were 2 -aminochalcone (55\%) and 2'-aminochalcone with the C-C double bound hydrogenated (1-(2aminophenyl)-3-phenylpropan-1-one) (19\%). Notice that 2'-nitrosochalcone, which is an intermediate reduction product of the 2'-nitrochalcone, was also detected (8\%) (Scheme 4).

However, it is possible to achieve high yields of the final product in a one pottwo steps reaction. The, best results in terms of yield and selectivity to 2,3dihydro-2-phenyl- $4(1 \mathrm{H})$-quinolinone were obtained in the presence of a mixture of $\mathrm{MCM}-41(15)$ and $0.2 \% \mathrm{Pt} / \mathrm{TiO}_{2}$, with the following experimental procedure: In a first step hydrogenation process of 2 -nitrochalcone was carried out under 9 bar hydrogen pressure of and $70{ }^{\circ} \mathrm{C}$ in toluene as a solvent. Thus, after $40 \mathrm{~min}$ reaction time a $60 \%$ yield of dihydroquinolinone and $40 \%$ of 2'-aminochalcone were obtained, while only traces of (1-(2-aminophenyl)-3-phenylpropan-1-one) were detected in the reaction mixture. At this point, $\mathrm{H}_{2}$ was changed by $\mathrm{N}_{2}$, the temperature was raised to $100 \stackrel{\circ}{\circ} \mathrm{C}$ and the reaction continued for 40 more minutes. After that time, $97 \%$ yield with $98 \%$ selectivity of dihydroquinolinone was obtained. Therefore, dihydroquinolinones can be obtained in excellent yields directly from $2^{\prime}$-nitrochalcones in a reasonable time $(1.3 \mathrm{~h})$ in a one pot system (see Figure 8 ) being the catalyst reused several times. This process avoids intermediate separation, purification and neutralization steps as will be necessary when using homogeneous catalysts.

\section{Conclusions}

It has been shown that the use of zeolites (with Bronsted or Lewis acid sites) as catalysts for the intramolecular aza-Michael cyclization of 2'-aminochalcones 
leads to low yield of dihydroquinolinone due to a deactivation of the catalyst. These results are attributed to the existence of diffusional limitations for the reactant and product in the pore of the zeolite and especially to the strong adsorption of the product. Higher catalytic activity was observed on delaminated ITQ-2 zeolite but, a catalyst deactivation due to the strong adsorption of the basic dihydroquinolinone was still found. Mesoporous aluminosilicate MCM41(Si/Al=15) with much larger pore diameter and milder acidity than zeolites was the most active catalyst achieving $94 \%$ conversion of $2^{\prime}$-aminochalcone with $100 \%$ selectivity to dihydroquinolinone. A variety of dihydroquinolinones of pharmaceutical interest have been obtained with excellent yields and selectivities (95-99\%). Finally, it has been showed that dihydroquinolinone can be chemoselectively prepared in one pot-two steps process starting from 2'nitrochalcone in the presence of $\mathrm{MCM}-41(15)$ and $0.2 \% \mathrm{Pt} / \mathrm{TiO}_{2}$. Excellent yields $(97 \%)$ and selectivity (98\%) in a short reaction time (1.5h) were obtained and the catalyst can be reused at least up to five consecutive cycles without loss of activity.

\section{Experimental Section}

\section{$\underline{\text { Reagents }}$}

2'-Aminochalcones were prepared starting from the corresponding 2'nitroacetophenones and benzaldehyde derivatives following the one-pot process developed previously. ${ }^{[26]}$ Toluene $(\geq 99.9 \%)$, acetonitrile $(\geq 99.9 \%)$ and THF ( $\geq 99.9 \%)$, p-toluenesulfonic acid (99.8\%) were purchased from Aldrich and ethanol $(\geq 99.9 \%)$ was purchased from Scharlau.

\section{Catalysts preparation and characterization}

H-Mordenite (CBV-20A)(crystal diameter 100-200 nm), H-Al-Beta (CP 811) with 
crystal diameter between 25-40 nm, USY (CBV 712) with crystal diameter between 25-30 nm, were purchased from PQ ZEOLITES B.V. and before use, they were calcined at $580{ }^{\circ} \mathrm{C}$ for $10 \mathrm{~h}$. The following catalysts were prepared according to the literature: Al-MCM-41 with different Si/Al ratio, ${ }^{[44]}$ Sn-MCM$41,{ }^{[45]}$ Si-MCM-41 ${ }^{[46]}$ and nanocrystalline Beta with crystal diameter between 10$20 \mathrm{~nm}^{[47]}$

The samples Sn-Beta (2wt\%) and Zr-Beta (1wt\%) were prepared following the method described in the literature ${ }^{[48]}[49]$

The delaminated ITQ-2 and the MCM-22 zeolite precursor were synthesized accordingly a previously described method. ${ }^{29]}$

The acidity of the catalysts was measured by IR spectroscopy (Nicolet 750 Spectrophotometer) combined with the adsorption-desorption of pyridine. Pyridine was adsorbed on the catalysts and desorbed at different temperatures and the pyridine remaining on the catalysts was followed using infrared spectroscopy (IR). More specifically, wafers of $10 \mathrm{mg} \mathrm{cm}^{-2}$ were degassed overnight under vacuum $\left(10^{-9}\right.$ to $10^{-10}$ bar $)$ at $400{ }^{\circ} \mathrm{C}$. The spectra were recorded, and pyridine was then introduced. After equilibration, the samples were outgassed at 150,250 and $350{ }^{\circ} \mathrm{C}$ for $1 \mathrm{~h}$ under vacuum. After each desorption step, the spectrum was recorded at room temperature and the background subtracted. Hence, following the above procedure, the acidity of the catalysts was determined on the basis of a method already described in the literature. ${ }^{[50]}$

Thermogravimetric analysis (TGA) was performed by using a Netzsch STA 409 EP thermal analysis with approximately $20 \mathrm{mg}$ of sample and a heating rate of $10{ }^{\circ} \mathrm{C} \mathrm{min}^{-1}$ until $600{ }^{\circ} \mathrm{C}$ in an air flow. The solids were characterized by $\mathrm{X}$-ray diffraction on a Philips PW diffractometer using CuKa radiation. Surface area measurements and pore volume were obtained on a Micrometrics ASAP-2000 apparatus by nitrogen and argon adsorption experiments at 77 and $85 \mathrm{~K}$, respectively following the BET procedure. The main characteristics of the catalysts are summarized in Table 2. 
$0.2 \% \mathrm{Pt} / \mathrm{TiO}_{2}$ with a Pt particle size of $1.5 \mathrm{~nm}$ was prepared according to ref. ${ }^{[51]}$ $0.1 \mathrm{Pt}-\mathrm{MCM}-41$ (15) and 0.5Pt-MCM-41(15) were prepared by impregnation ${ }^{[52]}$ of the support previously calcined (at $540{ }^{\circ} \mathrm{C}$ in air flow during 10h) with the required amount of $\mathrm{H}_{2} \mathrm{PtCl}_{6} \cdot 6 \mathrm{H}_{2} \mathrm{O}$ in a $0.1 \mathrm{M}$ aqueous solution of $\mathrm{HCl}(3 \mathrm{~mL}$ per gram of solid). The mixture was stirred during $30 \mathrm{~min}$ and then the solvent was evaporated. The solid recovered was dried at $100{ }^{\circ} \mathrm{C}$ during $12 \mathrm{~h}$ and, then calcined at $500{ }^{\circ} \mathrm{C}$ in $\mathrm{N}_{2}$ flow for $3 \mathrm{~h}$ and finally reduced under $\mathrm{H}_{2}$ flow at $450{ }^{\circ} \mathrm{C}$ during $3 \mathrm{~h}$. The nominal platinum content was 0.1 and $0.5 \mathrm{wt} \%$ for $0.1 \mathrm{Pt}-\mathrm{MCM}$ 41(15) and 0.5Pt-MCM-41(15) samples respectively.

\section{$\underline{\text { Reaction procedures }}$}

General procedure for the preparation of 2-phenyl-2,3-dihydroquinolin-4(1H)one:

A mixture of 2'-aminochalcone $(1 \mathrm{mmol})$ and 1,1'-biphenyl as internal standard $(0.5 \mathrm{mmol})$ was dissolved in toluene $(0.5 \mathrm{~mL})$ and added over $8 \mathrm{wt} \%$ of the activated catalyst in a closed reactor vessel. The resultant suspension was stirred at the desired temperature under inert atmosphere.

One pot procedure for the preparation of 2-phenyl-2,3-dihydroquinolin-4(1H)one from o-nitrochalcone:

2'-Nitrochalcone $(0.5 \mathrm{mmol})$ and $1,1^{1}$-biphenyl as internal standard $(0.5 \mathrm{mmol})$ was dissolved in $0.5 \mathrm{~mL}$ of toluene and added over a mixture of $15 \mathrm{mg}$ $0.2 \% \mathrm{Pt} / \mathrm{TiO}_{2}, 15 \mathrm{mg} \mathrm{MCM}-41(15)$. The first step of hydrogenation of 2 nitrochalcone was carried out at hydrogen pressure of 9 bar and $70 \stackrel{\circ}{\circ}$ during 40 min under stirring. Then, the temperature was raised to $100{ }^{\circ} \mathrm{C}$ and the atmosphere of $\mathrm{H}_{2}$ was changed to $\mathrm{N}_{2}$ to carry out the cyclization step into 2phenyl-2,3-dihydroquinolin-4(1H).

Samples of the reaction mixture were periodically taken by a filtering syringe and analysed by gas chromatography (HP spectrometer provided with a $30 \mathrm{~m} x$ $0.25 \mathrm{~mm}$ capillary column of $0.25 \mathrm{~mm}$ cross-linked $5 \%$ phenylmethylsiloxane) and FID detector. Mass spectra were performed by GC-MS HP Agilent 5973 with a 6980 mass selective detector. 
For catalyst recycling studies, the solid was collected by filtration, washed thoroughly with $\mathrm{CH}_{2} \mathrm{Cl}_{2}$ and calcined at $540 \stackrel{\circ}{\circ} \mathrm{C}$ in air flux during $10 \mathrm{~h}$ after each run to remove the adsorbed species.

Spectral data of the reaction products

${ }^{1} \mathrm{H}$ NMR spectra were recorded at $300 \mathrm{MHz}$ and ${ }^{13} \mathrm{C}$ at $75 \mathrm{MHz}$ in a Bruker Avance 300 spectrometer, and the chemical shifts in parts per million (ppm) were reported to internal TMS.

\section{1-(2-aminophenyl)-3-phenylprop-2-en-1-one (1) :}

${ }^{1} \mathrm{H}-\mathrm{NMR}\left(\mathrm{CDCl}_{3}, 300 \mathrm{MHz}\right): \delta 7.875$ (dd, 8.29, $\left.1.32 \mathrm{~Hz}, 1 \mathrm{H}\right) ; 7.75$ (d, $15.45 \mathrm{~Hz}$, 1H); 7.65-7.59 (m, 3H); 7.44-7.39 (m, 3H); 7.31 (dd, 15.45, $1.51 \mathrm{~Hz}, 1 \mathrm{H}) ; 6.72$ (td, 8.29, $1.13 \mathrm{~Hz}, 2 \mathrm{H}$ ); 6.51 (broad, 2H). ${ }^{13} \mathrm{C}-\mathrm{NMR}\left(\mathrm{CDCl}_{3}, 75 \mathrm{MHz}\right): \delta 192$ (C), $150(\mathrm{C}), 143(\mathrm{CH}), 135(\mathrm{C}), 134(\mathrm{CH}), 131(\mathrm{CH}), 130(\mathrm{CH}), 129(\mathrm{CH}), 128$ (3CH), $126(\mathrm{C}), 123(\mathrm{CH}), 117(\mathrm{CH}), 116(\mathrm{CH}) . \mathrm{MS}$ m/z (\%) $222\left(\mathrm{M}^{+}-1,89\right), 194$ (12), 146 (100), 120 (15), 92 (21), 65 (24), 39 (7).

\section{2-phenyl-2,3-dihydroquinolin-4(1H)-one (2):}

${ }^{1} \mathrm{H}-\mathrm{NMR}\left(\mathrm{CDCl}_{3}, 300 \mathrm{MHz}\right): \delta 7.89$ (ddt, 7.95, 1.6, $\left.0.6 \mathrm{~Hz}, 1 \mathrm{H}\right) ; 7.51-7.31$ (m, $6 \mathrm{H}) ; 6.55$ (dd, 7.21, $1.05 \mathrm{~Hz}, 1 \mathrm{H}) ; 6,73$ (dq, 8.25, $0.6 \mathrm{~Hz}, 1 \mathrm{H}) ; 4.6$ (dd, 13.41, 4,17 Hz, 1H); 4.5 (sa, 1H), 2.96 (dd, 16.23, $13.41 \mathrm{~Hz}, 1 \mathrm{H}$ ); 2.8 (ddd, 16.23, 4.17, 1.7Hz, 1H): ${ }^{13} \mathrm{C}-\mathrm{NMR}\left(\mathrm{CDCl}_{3}, 75 \mathrm{MHz}\right): \delta$ 193(C), 151 (C), 141 (C), 135 $(\mathrm{CH}), 129(\mathrm{CH}), 128(\mathrm{CH}), 127(\mathrm{CH}), 126(\mathrm{CH}), 119(\mathrm{C}), 118(\mathrm{CH}), 116(\mathrm{CH}), 58$ (CH), 46( $\left.\mathrm{CH}_{2}\right) . \mathrm{MS} \mathrm{m} / \mathrm{z}(\%) 223\left(\mathrm{M}^{+}, 100\right), 206$ (12), 180 (7), 146 (87), $119(22)$, 105 (10), 92 (16), 76 (16), 51 (7).

\section{1-(2-Aminophenyl)-3-phenylpropan-1-one}

${ }^{1} \mathrm{H}$ NMR $\left(\mathrm{CDCl}_{3}, 300 \mathrm{MHz}\right): \delta 7.66(\mathrm{dd}, 8.01,1.41 \mathrm{~Hz}, 1 \mathrm{H}) ; 7.25-7.1(\mathrm{~m}, 6 \mathrm{H})$;

6.57 (d, $8.34 \mathrm{~Hz}, 1 \mathrm{H}) ; 6.54$ (td, $7.08 \mathrm{~Hz}, 1 \mathrm{H}) ; 6.1$ (s, 2H); 3.25 (t, $8.4 \mathrm{~Hz}, 2 \mathrm{H}) ; 3$

$(\mathrm{t}, 8.34 \mathrm{~Hz}, 2 \mathrm{H}) .{ }^{13} \mathrm{C} \mathrm{NMR}\left(\mathrm{CDCl}_{3}, 75 \mathrm{MHz}\right): \delta 201$ (C), 150 (C), $142(\mathrm{C}), 141$ 
(C), $134(\mathrm{CH}), 131(\mathrm{CH}), 129(\mathrm{CH}), 128(\mathrm{CH} \times 2), 127(\mathrm{CH}), 126(\mathrm{CH}), 117(\mathrm{CH})$, $116(\mathrm{CH}), 41\left(\mathrm{CH}_{2}\right), 30\left(\mathrm{CH}_{2}\right)$.

1-(2-aminophenyl)-3-(4-chlorophenyl)prop-2-en-1-one (1a):

${ }^{1} \mathrm{H}-\mathrm{NMR}\left(\mathrm{CDCl}_{3}, 300 \mathrm{MHz}\right): \delta 7.75$ (dd, 8.43, $\left.1.53 \mathrm{~Hz}, 1 \mathrm{H}\right) ; 7.55$ (q, $15.6 \mathrm{~Hz}$, 2H); 7.45 (dt, 84, 1,7.1 Hz, 2H); 7.30 (dt, 8.49, $1.83 \mathrm{~Hz}, 2 \mathrm{H}$ ); 7.20 (td, 8.37, 1.5 $\mathrm{Hz}, 1 \mathrm{H}$ ); 6.61 (tt, 7.14, $1.14 \mathrm{~Hz}, 1 \mathrm{H}$ ); 6.62 (dd, 8.28, $1.26 \mathrm{~Hz}, 1 \mathrm{H}$ ); 6.27 (broad, 2H). ${ }^{13} \mathrm{C}-\mathrm{NMR}\left(\mathrm{CDCl}_{3}, 75 \mathrm{MHz}\right): \delta 191(\mathrm{C}), 151(\mathrm{C}), 141(\mathrm{CH}), 136(\mathrm{C}), 134$ (CH), $133(\mathrm{C}), 131(\mathrm{CH}), 129$ (CHx2), $123(\mathrm{CH}), 119(\mathrm{C}), 117(\mathrm{C}), 116(\mathrm{C}) . \mathrm{MS}$ m/z (\%) $256\left(M^{+}-1,33\right), 146$ (100), 120 (9), 92 (13), 65 (12), 39 (3).

\section{2-(4-chlorophenyl)-2,3-dihydroquinolin-4(1 H)-one (2a):}

${ }^{1} \mathrm{H}-\mathrm{NMR}\left(\mathrm{CDCl}_{3}, 300 \mathrm{MHz}\right): \delta 7.87(\mathrm{~d}, 7.86 \mathrm{~Hz}, 1 \mathrm{H}) ; 7.43-7.26(\mathrm{~m}, 5 \mathrm{H}) ; 6.82(\mathrm{t}$, $7.2 \mathrm{~Hz}, 1 \mathrm{H}) ; 6.72(\mathrm{~d}, 8.19 \mathrm{~Hz}, 1 \mathrm{H}) ; 4.76$ (dd, 12.78, $4.53 \mathrm{~Hz}, 1 \mathrm{H}) ; 4.48$ (s, 1H); 2.8 (dd, 16.11, $12.09 \mathrm{~Hz}, 1 \mathrm{H}) ; 2.7$ (dd, 16.11, $4.44 \mathrm{~Hz}, 1 \mathrm{H}) .{ }^{13} \mathrm{C}-\mathrm{NMR}\left(\mathrm{CD}_{3} \mathrm{CN}\right.$, $75 \mathrm{MHz}$ ): $192(\mathrm{C}), 152(\mathrm{C}), 140(\mathrm{C}), 135(\mathrm{CH}), 129(\mathrm{CH}), 128(\mathrm{CHx}), 127(\mathrm{CH})$, $126(\mathrm{CH}), 118(\mathrm{C}), 117(\mathrm{CH}), 116(\mathrm{CH}), 56(\mathrm{CH}), 45\left(\mathrm{CH}_{2}\right) . \mathrm{MS} \mathrm{m} / \mathrm{z}(\%) 259$ $\left(M^{+}+2,31\right), 257\left(M^{+}, 91\right), 256$ (38), 242 (10), 222 (7), 167 (6), 146 (100), 119 (35), 92 (19), 77 (12).

\section{4-(3-(2-aminophenyl)-3-oxoprop-1-en-1-yl)benzonitrile (1b):}

${ }^{1} \mathrm{H}-\mathrm{NMR}\left(\mathrm{CDCl}_{3}, 300 \mathrm{MHz}\right): \delta 7.76$ (dd, 8.7, $\left.1.5 \mathrm{~Hz}, 1 \mathrm{H}\right) ; 7.63$ (s, 4H); 7.61 (s, 2H); 7.40 (d, $15.51 \mathrm{~Hz}, 1 \mathrm{H}) ; 7.24$ (td, 8.3, $1.5 \mathrm{~Hz}, 1 \mathrm{H}) ; 6.63$ (m, 2H); 6.3 (s, 2H); ${ }^{13} \mathrm{C}-\mathrm{NMR}\left(\mathrm{CDCl}_{3}, 75 \mathrm{MHz}\right): \delta 191(\mathrm{C}), 151(\mathrm{C}), 140(\mathrm{CH}), 139(\mathrm{C}), 135(\mathrm{CH})$, $133(\mathrm{CH}), 131(\mathrm{CH}), 128(\mathrm{CH}), 126(\mathrm{CH}), 119(\mathrm{C}), 118(\mathrm{C}), 117(\mathrm{CH}), 116(\mathrm{CH})$, 113 (C). MS m/z (\%) 247 (M+1, 67), 219 (10), 146 (100), 120 (16), 92 (19), 65 (21), 39 (6).

\section{4-(4-oxo-1,2,3,4-tetrahydroquinolin-2-yl)benzonitrile (2b):}

${ }^{1} \mathrm{H}-\mathrm{NMR}\left(\mathrm{CDCl}_{3}, 300 \mathrm{MHz}\right): \delta 7.87(\mathrm{~d}, 7.92 \mathrm{~Hz}, 1 \mathrm{H}) ; 7.7$ (d, $\left.8.01 \mathrm{~Hz}, 2 \mathrm{H}\right) ; 7.59$ 
(d, $8.13 \mathrm{~Hz}, 2 \mathrm{H}) ; 7.39$ (t, $6.9 \mathrm{~Hz}, 1 \mathrm{H}) ; 6.86$ (t, $7.53 \mathrm{~Hz}, 1 \mathrm{H}) ; 7.74$ (d, $8.22 \mathrm{~Hz}$, 1H), $4.86(\mathrm{dd}, 10.2,6.9 \mathrm{~Hz}, 1 \mathrm{H}) ; 4.5(\mathrm{~s}, 1 \mathrm{H}) ; 2.83(\mathrm{dd}, 16.32,10.44 \mathrm{~Hz}, 1 \mathrm{H})$; $2.81(\mathrm{dd}, 16.32,3.4 \mathrm{~Hz}, 1 \mathrm{H}) .{ }^{13} \mathrm{C}-\mathrm{NMR}\left(\mathrm{CD}_{3} \mathrm{CN}, 75 \mathrm{MHz}\right): 192(\mathrm{C}), 151$ (C), 146 (C), $136(\mathrm{CH}), 133(\mathrm{CH}), 128(\mathrm{CH}), 127(\mathrm{CH}), 119(\mathrm{C}), 129(\mathrm{CH}), 118(\mathrm{C}), 116$ (CH), $112(\mathrm{C}), 58(\mathrm{CH}), 46\left(\mathrm{CH}_{2}\right) . \mathrm{MS} \mathrm{m} / \mathrm{z}(\%) 248\left(\mathrm{M}^{+}, 100\right), 233(21), 219(9)$, 205 (9), 177 (6), 146 (99), 119 (29), 105 (16), 92 (24), 87 (13), 64 (10), 39 (4).

\section{1-(2-aminophenyl)-3-(4-methoxyphenyl)prop-2-en-1-one (1c):}

${ }^{1} \mathrm{H}-\mathrm{NMR}\left(\mathrm{CDCl}_{3}, 300 \mathrm{MHz}\right): \delta 7.80(\mathrm{dd}, 8.4,1.56 \mathrm{~Hz}, 1 \mathrm{H}) ; 7.65$ (d, $15.51 \mathrm{~Hz}$, 1H); 7.50 (dt, 9.63, $2.88 \mathrm{~Hz}, 2 \mathrm{H}) ; 7.40(\mathrm{~d}, 15.51 \mathrm{~Hz}, 1 \mathrm{H}) ; 7.20$ (dd, 7.05, 1.44 $\mathrm{Hz}, 1 \mathrm{H}) ; 6.8$ (dt, 9.63, $2.88 \mathrm{~Hz}, 2 \mathrm{H}) ; 6.62$ (td, 7.1, $1.14 \mathrm{~Hz}, 1 \mathrm{H}) ; 6.61$ (dd, 8.25, $1.24 \mathrm{~Hz}, 1 \mathrm{H}) ; 6.20$ (s, 2H); 2,30 (s, 3H). ${ }^{13} \mathrm{C}-\mathrm{NMR}\left(\mathrm{CDCl}_{3}, 75 \mathrm{MHz}\right): \delta 192(\mathrm{C})$, $161(\mathrm{C}), 151(\mathrm{C}), 143(\mathrm{CH}), 134(\mathrm{CH}), 131(\mathrm{CH}), 130(\mathrm{CH}), 128(\mathrm{C}), 121(\mathrm{CH})$, $119(\mathrm{C}), 117(\mathrm{CH}), 116(\mathrm{CH}), 114(\mathrm{CH}), 55\left(\mathrm{CH}_{3}\right) . \mathrm{MS} \mathrm{m} / \mathrm{z}(\%) 252\left(\mathrm{M}^{+}-1,100\right)$, 236 (31), 209 (22), 180 (13), 164 (10), 146 (99), 120 (22), 92 (31), 65 (25), 39 (6).

\section{2-(4-methoxyphenyl)-2,3-dihydroquinolin-4(1H)-one (2c):}

${ }^{1} \mathrm{H}-\mathrm{NMR}\left(\mathrm{CDCl}_{3}, 300 \mathrm{MHz}\right): \delta 7.87$ (dd, 7.95, $\left.1.05 \mathrm{~Hz}, 1 \mathrm{H}\right) ; 7.4-7.3(\mathrm{~m}, 4 \mathrm{H}) ; 6.94$ (d, $8.7 \mathrm{~Hz}, 1 \mathrm{H}) ; 6.8$ (t, $7.08 \mathrm{~Hz}, 1 \mathrm{H}) ; 6.7$ (d, $8.22 \mathrm{~Hz}, 1 \mathrm{H}) ; 4.7$ (dd, 13.65, 3.84 $\mathrm{Hz}, 1 \mathrm{H}) ; 3.9$ (2, 3H); 2.8 (dd, 16.23, $13.65 \mathrm{~Hz}, 1 \mathrm{H}) ; 2.7$ (dd, 16.23, 3.93 Hz, 1H). ${ }^{13} \mathrm{C}-\mathrm{NMR}\left(\mathrm{CD}_{3} \mathrm{CN}, 75 \mathrm{MHz}\right): 193$ (C), 160 (C), $152(\mathrm{C}), 135(\mathrm{CH}), 133(\mathrm{C}), 129$ $(\mathrm{CH}), 128(\mathrm{C}), 127(\mathrm{CH} 2), 119(\mathrm{C}), 118(\mathrm{CH}), 115(\mathrm{CH}), 114(\mathrm{CH}), 58(\mathrm{CH}), 55$ $\left(\mathrm{CH}_{3}\right), 47\left(\mathrm{CH}_{2}\right)$. MS m/z (\%) $253\left(\mathrm{M}^{+}, 100\right), 238$ (10), 222 (10), 209 (6), 180 (4), 167 (4), 146 (82), 134 (26), 119 (24), 92 (13), 65 (7), 39 (3).

1-(2-aminophenyl)-3-(p-tolyl)prop-2-en-1-one (1d): 
${ }^{1} \mathrm{H}-\mathrm{NMR}\left(\mathrm{CDCl}_{3}, 300 \mathrm{MHz}\right): \delta 7.80(\mathrm{dd}, 8.4,1.5 \mathrm{~Hz}, 1 \mathrm{H}) ; 7.65(\mathrm{~d}, 15.54 \mathrm{~Hz}, 1 \mathrm{H})$; 7.50 (d, $15.54 \mathrm{~Hz}, 1 \mathrm{H}) ; 7.45$ (s, 1H); 7.20 (td, 8.4, $1.5 \mathrm{~Hz}, 2 \mathrm{H}) ; 7.15$ (d, $8.1 \mathrm{~Hz}$, 2H); $6.62(\mathrm{td}, 8.28,1.14 \mathrm{~Hz}, 1 \mathrm{H}) ; 6.61$ (dd, 8.28, $1.2 \mathrm{~Hz}, 1 \mathrm{H}) ; 6.22(\mathrm{~s}, 2 \mathrm{H}) ; 2,30$ (s, 3H). ${ }^{13} \mathrm{C}-\mathrm{NMR}\left(\mathrm{CDCl}_{3}, 75 \mathrm{MHz}\right): \delta$ 192(C), $151(\mathrm{C}), 142(\mathrm{CH}), 140(\mathrm{C}), 136$ $(\mathrm{CH}), 135(\mathrm{C}), 132(\mathrm{CH}), 129(\mathrm{CH}), 128(\mathrm{CH}), 122(\mathrm{CH}), 119(\mathrm{CH}), 117(\mathrm{C}), 115$ (CH), 21( $\left.\mathrm{CH}_{3}\right) . M S \mathrm{~m} / \mathrm{z}(\%) 236\left(\mathrm{M}^{+}-1,81\right), 146$ (100), 115 (16), 92 (13), 65 (18), 39 (4).

\section{2-(p-tolyl)-2,3-dihydroquinolin-4(1H)-one (2d):}

${ }^{1} \mathrm{H}-\mathrm{NMR}\left(\mathrm{CDCl}_{3}, 300 \mathrm{MHz}\right): \delta 7.8(\mathrm{~d}, 7.92 \mathrm{~Hz}, 1 \mathrm{H}) ; 7.3-7.1(\mathrm{~m}, 5 \mathrm{H}) ; 6.71$ (t, 7.11 $\mathrm{Hz}, 1 \mathrm{H}) ; 6.6$ (d, $8.13 \mathrm{~Hz}, 1 \mathrm{H}) ; 4.65$ (dd, 13.56, 3.93 Hz, 1H); 4.4 (s, 1H); 2.8 (dd, 16.23, $13.62 \mathrm{~Hz}, 1 \mathrm{H}$ ); 2.67 (dd, 16.23, $3.9 \mathrm{~Hz}, 1 \mathrm{H}$ ); 2.3 (s, 3H). ${ }^{13} \mathrm{C}-\mathrm{NMR}$ $\left(\mathrm{CD}_{3} \mathrm{CN}, 75 \mathrm{MHz}\right): 193(\mathrm{C}), 160(\mathrm{C}), 162(\mathrm{C}), 135(\mathrm{CH}), 133(\mathrm{C}), 129(\mathrm{CH}), 128$ $(\mathrm{CH}), 127(\mathrm{CH} 2), 119(\mathrm{C}), 118(\mathrm{CH}), 116(\mathrm{CH}), 114(\mathrm{CH}), 58(\mathrm{CH}), 55\left(\mathrm{CH}_{3}\right)$, $47\left(\mathrm{CH}_{2}\right) . \mathrm{MS}$ m/z (\%) 237 (M+, 100), 222 (24), 194 (7), 165 (4), 146 (91), 119 (31), 115 (12), 92 (18), 77 (9), 65 (9), 39 (3).

\section{Acknowledgements}

Financial support by Consolider-Ingenio 2010 (project MULTICAT), Spanish MICINN Project (CTQ-2011-27550), Generalitat Valenciana (Prometeo program) and Program Severo Ochoa are gratefully acknowledged.

\section{References}

[1] P. Hradil, J. Hlavác, M. Soural, M. Hajdúch, M. Kolár, R. Vecerová, Mini Rev. Med. Chem. 2009, 9, 696-702.

[2] Larsen, R. D, Cai, D, in Six-Membered Hetarenes One Nitrogen Phosphorus At., Thieme: Stuttgart, 2005, pp. 551-660.

[3] Y. Xia, Z.-Y. Yang, P. Xia, K. F. Bastow, Y. Tachibana, S.-C. Kuo, E. Hamel, T. Hackl, K.-H. Lee, J. Med. Chem. 1998, 41, 1155-1162.

[4] O. Prakash, D. Kumar, R. K. Saini, S. P. Singh, Synth. Commun. 1994, 24, 2167-2172. 
[5] V. N. Kalinin, M. V. Shostakovsky, A. B. Ponomaryov, Tetrahedron Lett. 1992, 33, 373-376.

[6] A. S. Wagman, M. P. Wentland, in Compr. Med. Chem. II (Ed.: J.B.T.J. Triggle), Elsevier, Oxford, 2007, pp. 567-596.

[7] J. A. Donnelly, D. F. Farrell, J. Org. Chem. 1990, 55, 1757-1761.

[8] A. Fournet, B. Vagneur, P. Richomme, J. Bruneton, Can. J. Chem. 1989, $67,2116-2118$.

[9] S. Torii, H. Okumoto, L. H. Xu, Tetrahedron Lett. 1991, 32, 237-240.

[10] O. E. O. Hormi, C. Peltonen, L. Heikkila, J. Org. Chem. 1990, 55, 25132515.

[11] J. Baldwin, J. Chem. Soc.-Chem. Commun. 1976, 734-736.

[12] X. Zheng, H. Jiang, J. Xie, Z. Yin, H. Zhang, Synth. Commun. 2013, 43, 1023-1029.

[13] S. Chandrasekhar, K. Vijeender, C. Sridhar, Tetrahedron Lett. 2007, 48, 4935-4937.

[14] D. Kumar, G. Patel, B. G. Mishra, R. S. Varma, Tetrahedron Lett. 2008, 49, 6974-6976.

[15] Chunguang Yang, Lizhen Fang, Liqiang Wu, Fulin Yan, Asian J. Chem. 2010, 22, 6031-6034.

[16] E. Tang, B. Chen, L. Zhang, W. Li, J. Lin, Synlett 2011, 2011, 707-711.

[17] V. K. Rao, M. S. Rao, A. Kumar, J. Heterocycl. Chem. 2011, 48, 13561360.

[18] U. P. Lad, M. A. Kulkarni, U. V. Desai, P. P. Wadgaonkar, Comptes Rendus Chim. 2011, 14, 1059-1064.

[19] R. Sakirolla, M. Yaeghoobi, N. Abd. Rahman, Monatshefte Für Chem. Chem. Mon. 2012, 143, 797-800.

[20] N. Ahmed, J. E. van Lier, Tetrahedron Lett. 2006, 47, 2725-2729.

[21] P. T. P. K. Hemanth Kumar, Can. J. Chem.-Rev. Can. Chim. - CAN J CHEM 2006, 84, 1079-1083.

[22] N. Ahmed, J. E. van Lier, Tetrahedron Lett. 2007, 48, 13-15.

[23] R. S. Varma, J. Heterocycl. Chem. 1999, 36, 1565-1571.

[24] M. J. Climent, A. Corma, S. Iborra, Chem. Rev. 2011, 111, 1072-1133.

[25] a) D.Tichit, C. Gerardin, R. Durand, B. Coq, Top. Catal. 2006, 39, 89-96; b) M. J. Climent, A. Corma, S. Iborra, M. J. Sabater, ACS Catal. 2014, 4, 870-891. [26] M. J. Climent, A. Corma, S. Iborra, L. Martí, ACS Catal. 2014, 5, 157-166.

[27] A. Reyes, P. A. Cuervo, F. Orozco, R. Abonia, M. Duque-Noreña P. Pérez, E. Chamorro, J. Mol. Model. 2013, 19, 3611-3618.

[28] G. Giordano, A. Macario, A. Aloise, J.B. Nagy, Silica and Silicates in Modern Catalysis 2010, 121-149.

[29] I. Rodriguez, M. J. Climent, S. Iborra, V. Fornés, A. Corma, J. Catal. 2000, 192, 441-447.

[30] M. J. Bhanushali, N. S. Nandurkar, S. R. Jagtap, B. M. Bhanage, Catal. Commun. 2008, 9, 1189-1195.

[31] M. Boronat, P. Concepción, A. Corma, M. T. Navarro, M. Renz, S. Valencia, Phys. Chem. Chem. Phys. 2009, 11, 2876-2884.

[32] A. Corma, M. Renz, M. Susarte, Top. Catal. 2009, 52, 1182-1189.

[33] D. Tichit, B. Coq, CATTECH, 2003, 7, 206-217.

[34] R. Chebout, D. Tichit, G. Layrac, A. Barama, B. Coq, J. Cota, Iuliana; R. E.

Ramirez, F. Medina, Solid State Sciences 2010, 12, 1013-1017.

[35] M. T. Drexler, M. D. Amiridis, J. Catal. 2003, 214, 136-145. 
[36] M. J. Climent, A. Corma, S. Iborra, J. Primo, J. Catal. 1995, 151, 60-66.

[37] T.-P. Loh, L.-L. Wei, Synlett 1998, 1998, 975-976.

[38] J. J. P. Furlong, N. S. Nudelman, J. Chem. Soc. Perkin Trans. 2 1985, 633-639.

[39] J. J. P. Furlong, N. S. Nudelman, J. Chem. Soc. Perkin Trans. 2 1988, 1213-1217.

[40] M. T. Drexler, M. D. Amiridis, Catal. Lett. 2002, 79, 175-181.

[41] D. Kumar, G. Patel, A. Kumar, R. K. Roy, J. Heterocycl. Chem. 2009, 46, 791-795.

[42] S. Wattanasin, W. S. Murphy, Synthesis 1980, 1980, 647-650.

[43] A. I. R. N. A. Barros, A. F. R. Dias, A. M. S. Silva, Monatshefte Für Chem. Chem. Mon. 2007, 138, 585-594.

[44] C. T. Kresge, M. E. Leonowicz, W. J. Roth, J. C. Vartuli, J. S. Beck, Nature 1992, 359, 710-712.

[45] A. Corma, M. T. Navarro, L. Nemeth, M. Renz, Chem. Commun. 2001, 2190-2191.

[46] J. S. Beck, J. C. Vartuli, W. J. Roth, M. E. Leonowicz, C. T. Kresge, K. D. Schmitt, C. T. W. Chu, D. H. Olson, E. W. Sheppard, J. Am. Chem. Soc. 1992, 114, 10834-10843.

[47] M. A. Camblor, A. Corma, A. Mifsud, J. Pérez-Pariente, S. Valencia, in Stud. Surf. Sci. Catal. (Ed.: S.-K.I. and Y.S.U. Hakze Chon), Elsevier, 1997, pp. 341-348.

[48] S.Valencia, A. Corma, US Patent 5968473, 1999.

[49]Y. Zhu, G. Chuah, S. Jaenicke, J. Catal. 2004, 227, 1- 10.

[50] C. A. Emeis, J. Catal. 1993, 141, 347-354.

[51] A. Corma, P. Serna, J. J. Calvino, J. Am. Chem. Soc. 2008, 130, 87488753.

[52] A. Corma, A. Martínez, V. Martínez-Soria, J. Catal. 1997, 169, 480-489. 
Table 1. Heterogeneous catalysts and reaction conditions for the synthesis of 2,3-dihydro-2-phenyl-4(1H)-quinolinone reported in the literature ${ }^{[a]}$

\begin{tabular}{|c|c|c|c|c|c|c|}
\hline Catalyst & $\begin{array}{l}\text { Catalyst } \\
\text { amount }\end{array}$ & Solvent & $\mathrm{T}\left({ }^{\circ} \mathrm{C}\right)$ & Time & $\begin{array}{l}\text { Yield } \\
(\%)\end{array}$ & Ref. \\
\hline $\mathrm{PMA} \mathrm{SiO}_{2}$ & $1 \mathrm{~mol} \%$ & $\mathrm{EtOH}$ & reflux & $18 \mathrm{~h}$ & 52 & [19] \\
\hline $\mathrm{TaBr}_{5}-\mathrm{SiO}_{2}$ & $5-10 \mathrm{~mol} \%$ & - & 150 & $3-5 \min$ & 92 & [20] \\
\hline $\mathrm{NaHSO}_{4}-\mathrm{SiO}_{2}$ & $\begin{array}{c}\mathrm{NaHSO}_{4}(2 \mathrm{~g}) \\
\mathrm{SiO}_{2}(2 \mathrm{~g})\end{array}$ & - & 150 & $8 \mathrm{~h}$ & $72(95)^{[c]}$ & [21] \\
\hline $\begin{array}{l}\mathrm{CeCl}_{3} 7 \mathrm{H}_{2} \mathrm{O} \\
\mathrm{Nal}-\mathrm{Al}_{2} \mathrm{O}_{3}\end{array}$ & $0.3-0.4 \mathrm{~g}$ & - & 70 & $2.5 \mathrm{~h}$ & 98 & [22] \\
\hline Montmorillonite & $1 \mathrm{~g}^{[\mathrm{b}]}$ & - & MW & $1.5 \mathrm{~min}$ & 80 & [23] \\
\hline
\end{tabular}


Table 2. Physicochemical properties of the catalysts

\begin{tabular}{|c|c|c|c|c|c|c|c|c|c|}
\hline \multirow{3}{*}{ Catalyst(Si/Al) } & \multirow{3}{*}{$\begin{array}{l}\text { Vmicrop. } \\
\left(\mathrm{cm}^{3} \mathrm{~g}^{-1}\right)^{[\mathrm{a}]}\end{array}$} & \multirow{3}{*}{$\begin{array}{l}\text { Pore size } \\
(\mathrm{nm})\end{array}$} & \multirow{3}{*}{$\begin{array}{c}\text { BET } \\
\left(m^{2} g^{-1}\right)\end{array}$} & \multicolumn{6}{|c|}{$\operatorname{Acidity}^{[\mathrm{b}]}\left(\mu \mathrm{mol}_{\text {pyridine }} \mathrm{g}_{\text {cat }}{ }^{-1}\right)$} \\
\hline & & & & \multicolumn{2}{|c|}{$150 \stackrel{\circ}{C}$} & \multicolumn{2}{|c|}{$250 \stackrel{\circ}{C}$} & \multicolumn{2}{|c|}{$350 \stackrel{\circ}{ } \mathrm{C}$} \\
\hline & & & & B & L & B & L & B & $\mathrm{L}$ \\
\hline Mordenite(10) & 0.17 & $\begin{array}{c}0.7^{*} 0.65 \\
0.57^{*} 0.26\end{array}$ & 550 & 67 & 25 & 54 & 25 & 29 & 28 \\
\hline HBeta(12) & 0.19 & $\begin{array}{l}0.75^{*} 0.57 \\
0.56^{*} 0.56 \\
075^{*} 0.57\end{array}$ & 602 & 65 & 69 & 58 & 56 & 25 & 29 \\
\hline $\mathrm{HBeta}_{\text {nano }}(8)$ & 0.19 & $0.56^{*} 0.56$ & 600 & 59 & 81 & 34 & 36 & 32 & 32 \\
\hline USY(5.6) & 0.25 & $0.74^{\star} 0.74$ & 593 & 58 & 25 & 49 & 19 & 31 & 14 \\
\hline ITQ-2(12) & 0.009 & $\begin{array}{l}\text { cups } \\
0.8^{\star} 0.7\end{array}$ & 643 & 57 & 27 & 37 & 18 & 16 & 13 \\
\hline MCM-41(15) & - & 3.2 & 1000 & 19 & 62 & 5 & 46 & 4 & 34 \\
\hline MCM-41(30) & - & 3.2 & 732 & 17 & 31 & 3 & 27 & 0 & 20 \\
\hline MCM-41(50) & - & 3.2 & 730 & 8 & 20 & 3 & 14 & 0 & 10 \\
\hline Si-MCM-41 & - & 3.2 & 1100 & - & - & - & - & - & - \\
\hline Sn-MCM-41(146) ${ }^{[c]}$ & - & 3.1 & 1110 & 0 & 13 & 0 & 6 & - & - \\
\hline Sn-Beta $(130)^{[\mathrm{cl}}$ & $\mathrm{nm}$ & $\begin{array}{l}0.75^{*} 0.57 \\
0.56^{*} 0.56\end{array}$ & 470 & 0 & 10 & 0 & 0 & - & - \\
\hline Zr-Beta(130) ${ }^{[d]}$ & $\mathrm{nm}$ & $\begin{array}{l}0.75^{*} 0.57 \\
0.56^{*} 0.56\end{array}$ & 482 & 0 & 15 & 0 & 0 & - & \\
\hline
\end{tabular}

[a] volume of micropore calculated from t-plot,

${ }^{[b]}$ acidity $\mu \mathrm{mol}$ of pyridine per gram catalyst calculated using extinction coefficients given in ref [50]. B: Bronsted acidity, L: Lewis acidity. ${ }^{[c]} \mathrm{Si} / \mathrm{Sn}$ molar ratio. ${ }^{[d]} \mathrm{Si} / \mathrm{Zr}$ molar ratio 
Table 3. Results of intramolecular aza-Michael cyclization of 2'aminochalcone in the presence of acid catalysts.

\begin{tabular}{|c|c|c|c|c|c|c|c|}
\hline Entry & Catalyst & $\begin{array}{c}r^{0} 10^{2} \\
\left(\mathrm{molh}^{-1} \mathrm{~g}^{-1}\right)\end{array}$ & $\begin{array}{c}\mathrm{TOF}^{[\mathrm{c}]} \\
\left(\mathrm{h}^{-1}\right)\end{array}$ & Time (h) & $\begin{array}{c}\text { Conv. } \\
(\%)\end{array}$ & $\begin{array}{c}\text { Yield } 2 \\
(\%)\end{array}$ & $\begin{array}{c}\text { Selec. } 2 \\
(\%)\end{array}$ \\
\hline 1 & Mordenite ${ }^{[a]}$ & 3.40 & 508 & 8 & 22 & 21 & 98 \\
\hline 2 & HBeta & 3.67 & 472 & 6 & 42 & 42 & 99 \\
\hline 3 & nanoBeta & 17 & 2882 & 8 & 92 & 92 & 100 \\
\hline 4 & USY & 16.28 & 2807 & 6 & 48 & 48 & 100 \\
\hline 5 & ITQ-2 & 10.90 & 1912 & 6 & 72 & 72 & 100 \\
\hline 6 & MCM-41(15) & 21.80 & 11476 & 1 & 94 & 94 & 100 \\
\hline 7 & MCM-41(30) & 6.80 & 2400 & 6 & 75 & 75 & 100 \\
\hline 8 & MCM-41(50) & 4.70 & 3525 & 6 & 62 & 62 & 100 \\
\hline 9 & Si-MCM-41 & 0.15 & - & 6 & 5 & 4.7 & 94 \\
\hline 10 & Sn-MCM-41 $1^{[a]}$ & 0.08 & 5 & 8 & 15 & 12 & 80 \\
\hline 11 & Sn-Beta & 1.55 & 92 & 8 & 59 & 59 & 100 \\
\hline 12 & Zr-Beta & 1.15 & 52 & 8 & 48 & 48 & 100 \\
\hline 13 & $p-T S A^{[b]}$ & - & - & 4 & 11 & 5 & 50 \\
\hline 14 & $\mathrm{AcH}-\mathrm{OPA} \mathrm{A}^{[\mathrm{d}]}$ & & & 6 & 85 & 85 & 100 \\
\hline 15 & blank & - & - & 8 & 5 & 2 & 43 \\
\hline
\end{tabular}

Reaction conditions: 2'-aminochalcone (1mmol), catalyst (8 wt\%), toluene $(0.5 \mathrm{~mL}), 100{ }^{\circ} \mathrm{C}$; ${ }^{[a]} 15 \mathrm{wt} \%$ of catalyst; ${ }^{[b]} 15 \mathrm{wt} \%$ catalyst at $30{ }^{\circ} \mathrm{C}$; ${ }^{[c]}$ Calculated as initial reaction rate $(\mathrm{mmol} / \mathrm{h})$ divided by the number of Bronsted acid sites measured at $150{ }^{\circ} \mathrm{C}$. [d] $15 \mathrm{wt} \%$ of a mixture of acetic acid and orthophosphoric acid $(1: 1 \mathrm{v} / \mathrm{v})$ as catalyst at $100^{\circ} \mathrm{C}$. 
Table 4. Composition of the organic material extracted by Soxhlet

\begin{tabular}{cccc}
\hline \multirow{2}{*}{ Catalyst } & Total amount $^{[\mathrm{a}]}(\%)$ & \multicolumn{2}{c}{ Composition of organic $(\%)^{[\mathrm{b}]}$} \\
& & Reactant (1) & Product (2) \\
\hline HBeta & 3 & 25 & 75 \\
USY & 14 & 3 & 97 \\
ITQ-2 & 43 & 31 & 69 \\
\hline
\end{tabular}

[a] wt \% of organic material extracted by Soxhlet (with respect to the amount of the catalyst) using dichloromethane

[b] Product distribution of the compounds in the organic extract 
Table 5. Results of Intramolecular aza-Michael cyclization of 2'-aminochalcone derivatives in the presence of MCM-41(15)
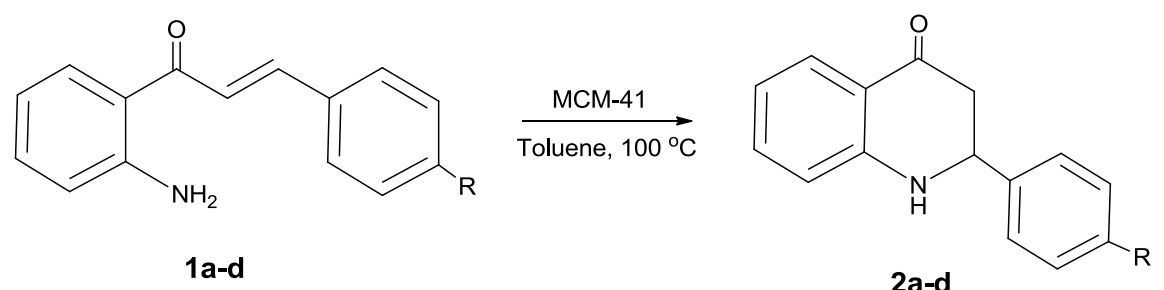

\begin{tabular}{|c|c|c|c|c|c|}
\hline Entry & $\mathrm{R}$ & $\stackrel{t}{t}$ & $\begin{array}{c}\text { Conv. } \\
(\%)\end{array}$ & $\begin{array}{l}\text { Yield } \\
(\%)\end{array}$ & Selectivity (\%) \\
\hline 1 & $\mathrm{H}$ & 15 & 98 & 95 & 97 \\
\hline 2 & $\mathrm{Cl}(\mathbf{a})$ & 180 & 100 & 98 & 98 \\
\hline 3 & $\mathrm{CN}(\mathbf{b})$ & 60 & 100 & 97 & 97 \\
\hline 4 & $\mathrm{OMe}(\mathbf{c})$ & 5 & 100 & 99 & 99 \\
\hline 5 & $\mathrm{Me}(\mathbf{d})$ & 5 & 100 & 98 & 98 \\
\hline
\end{tabular}




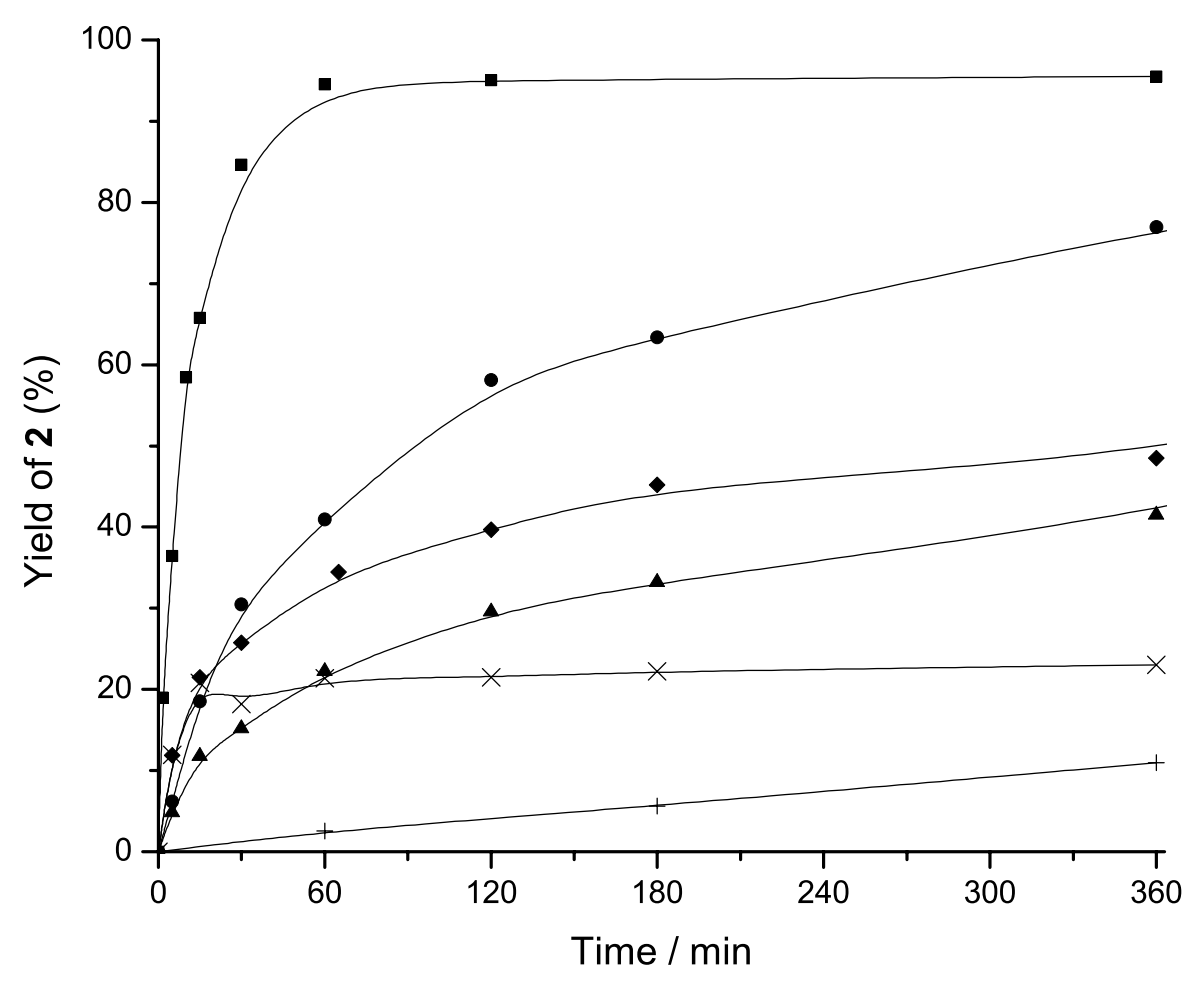

Figure 1. Kinetics curves of the yield to 2-phenyl-2,3-dihydroquinolin-4(1H)-one obtained for different solid acid catalysts (8wt \%) starting from 2'aminochalcone $(1 \mathrm{mmol})$ in toluene $(0.5 \mathrm{~mL})$ at $100{ }^{\circ} \mathrm{C}$. MCM-41 (匹), ITQ-2 $(\bullet)$, HBeta $(\boldsymbol{\Delta})$, USY $(\bullet), 15$ wt $\%$ of Mordenite $(\mathrm{x}), 15 \mathrm{wt} \%$ of Sn-MCM-41(+). 


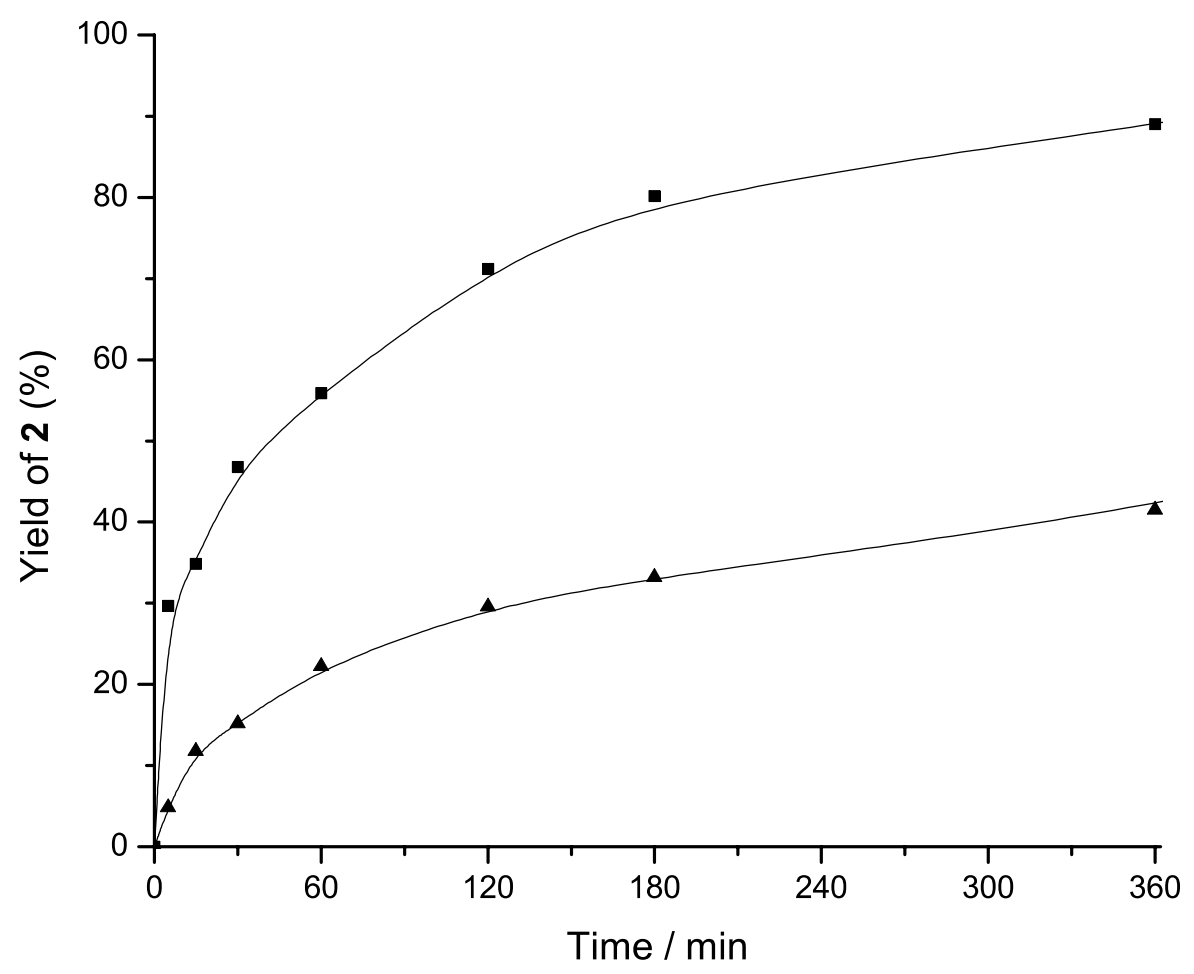

Figure 2. Yield of 2-phenyl-2,3-dihydroquinolin-4(1H)-one (2) versus time obtained for HBeta $(\boldsymbol{\Lambda})$ and Betanano ( $\mathbf{(})$ using 2'-aminochalcone $(1 \mathrm{mmol})$ in toluene $(0.5 \mathrm{~mL})$ at $100 \stackrel{\circ}{\circ}$. 


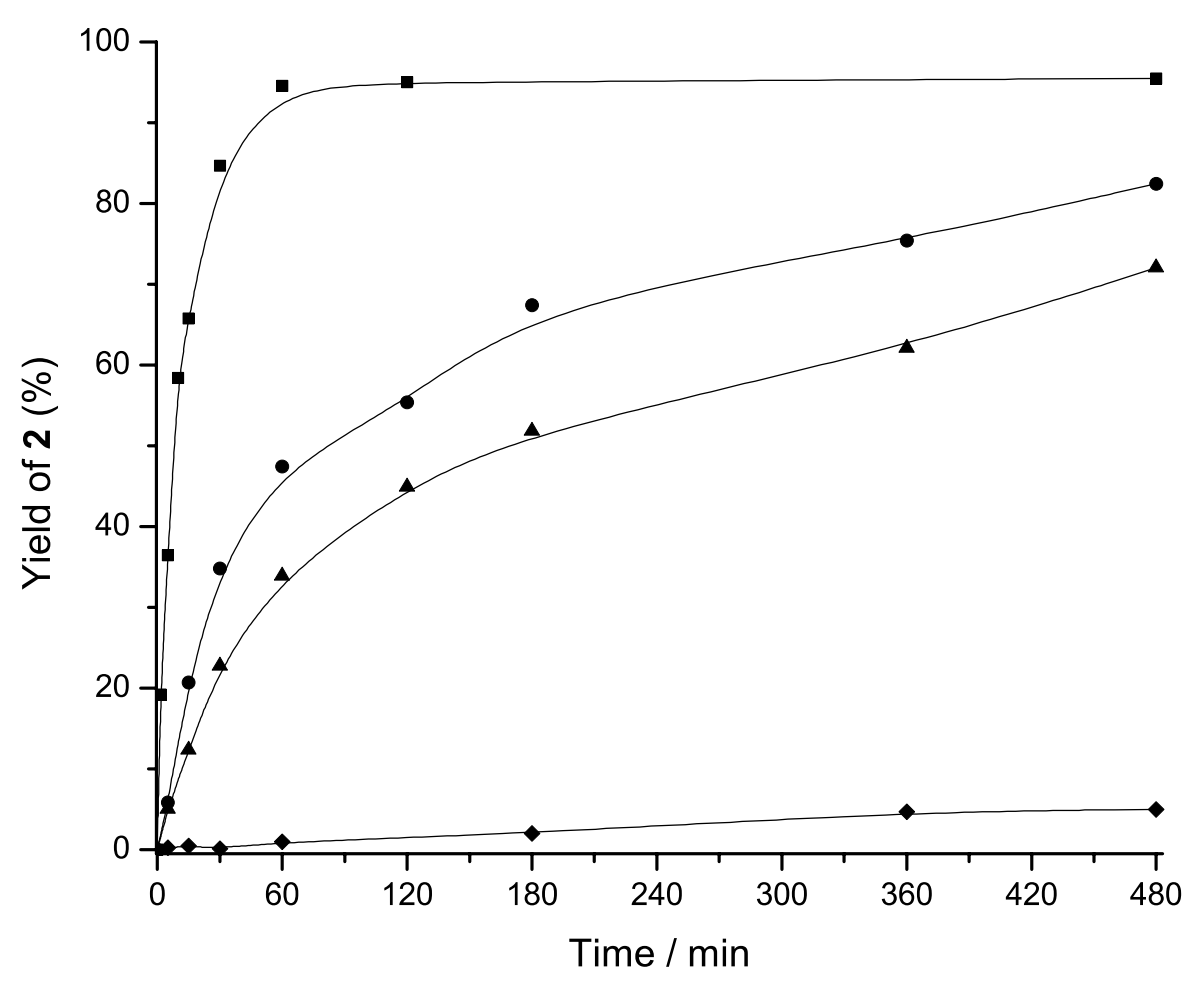

Figure 3. Yield of 2-phenyl-2,3-dihydroquinolin-4(1H)-one (2) versus time when the aza-Michael addition was performed using MCM-41 with different Si/Al ratios $=15(\boldsymbol{\square}), 30(\bullet), 50(\mathbf{\Delta})$, Si-MCM-41 $(\diamond)$ Reaction conditions: 2'aminochalcone $(1 \mathrm{mmol}), \mathrm{MCM}-41$ (8 wt \%), at $100 \stackrel{\circ}{\circ}$, in toluene $(0.5 \mathrm{~mL})$. 


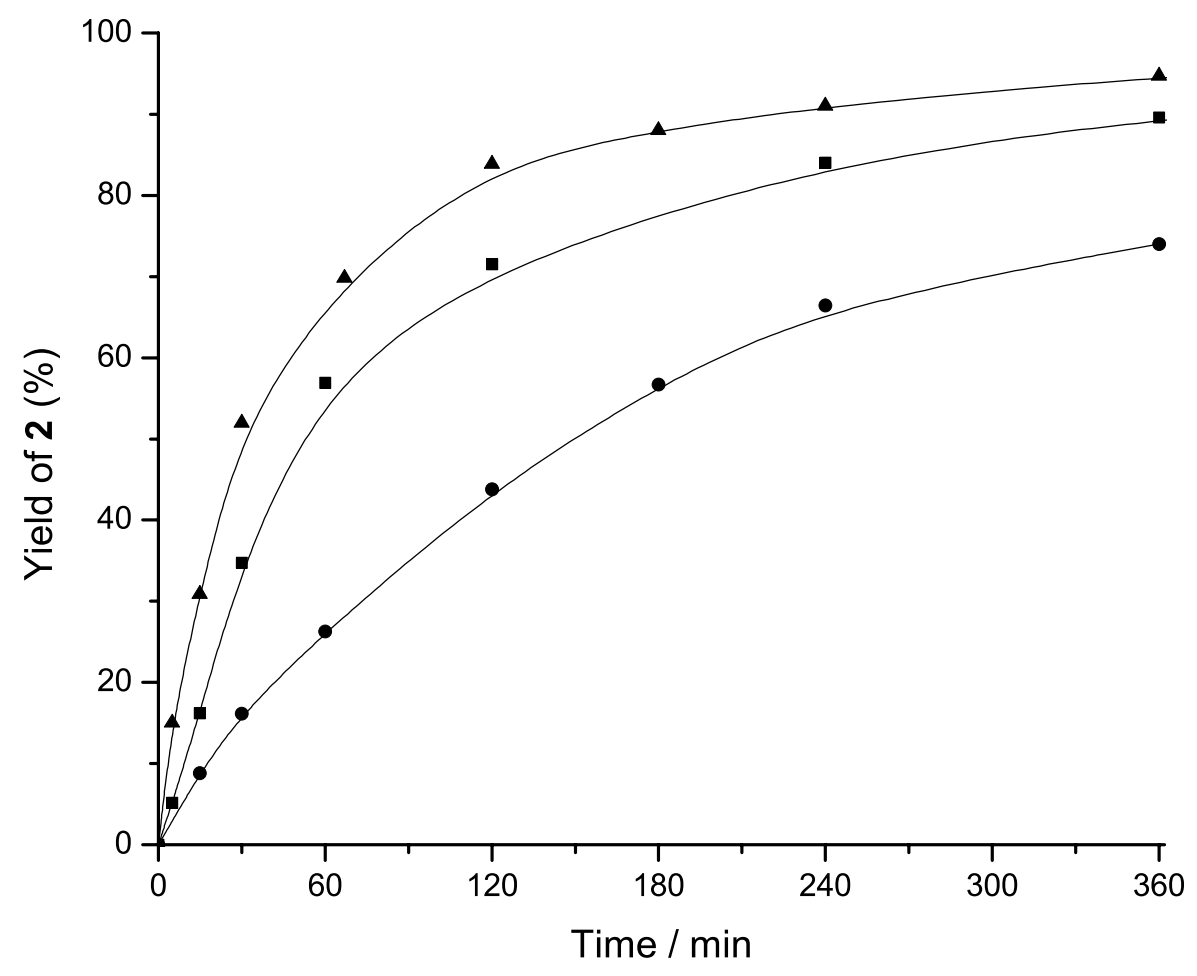

Figure 4. Kinetic curves of intramolecular aza-Michael cyclization of 2'aminochalcone in the presence of MCM-41(15) catalyst in different solvents: acetonitrile at $80{ }^{\circ} \mathrm{C}$, with $8 \mathrm{wt} \%$ of catalyst $(\mathbf{A})$, toluene at $80{ }^{\circ} \mathrm{C}$, with $8 \mathrm{wt} \%$ of catalyst ( $)$ and ethanol at $100 \stackrel{\circ}{\mathrm{C}}$ with $15 \mathrm{wt} \%$ catalyst $(\bullet)$. 


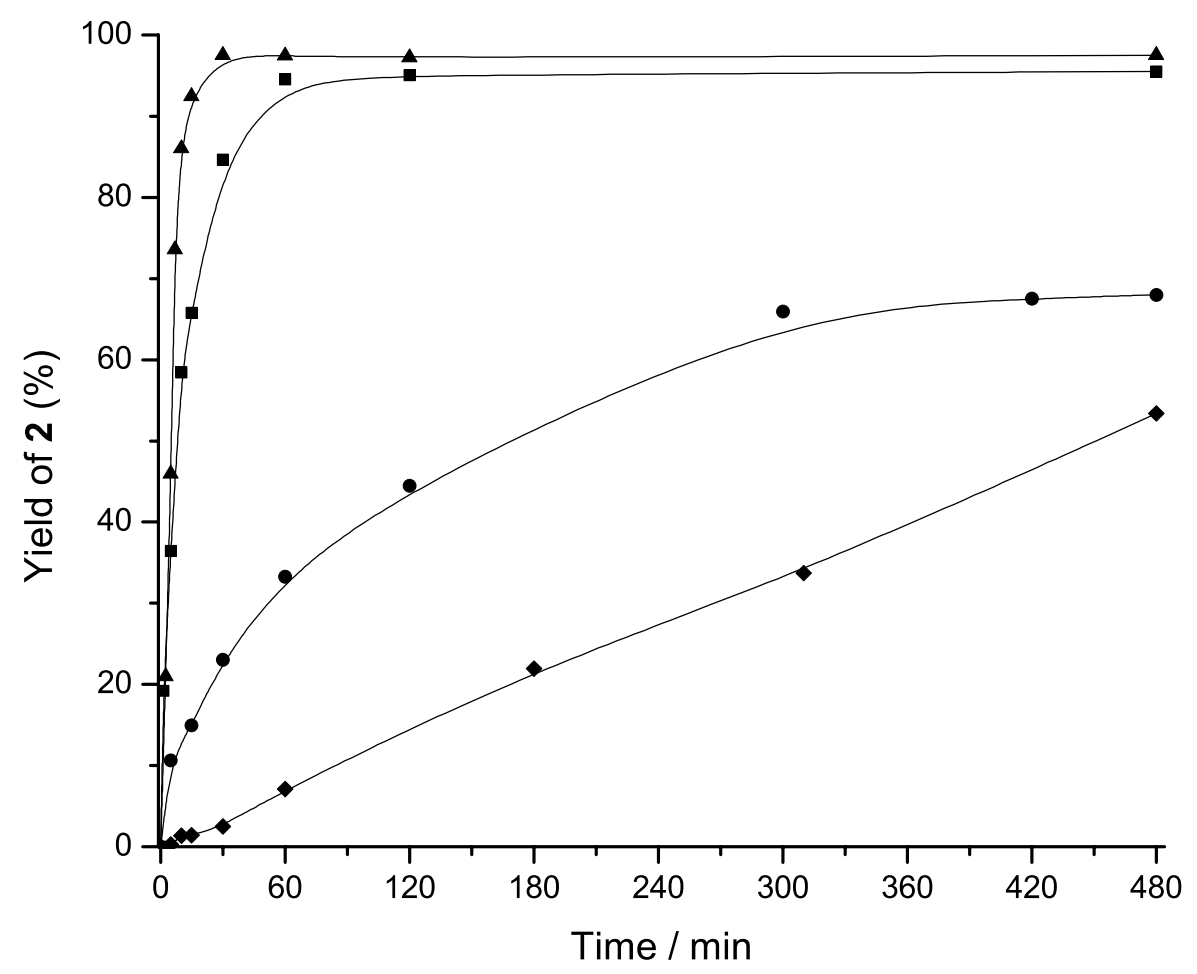

Figure 5. Cyclization of 2 -aminochalcone on MCM-41(15) in the presence of different solvents: acetonitrile $(\boldsymbol{\Delta})$, toluene $(\boldsymbol{\square})$. Second cycle in acetonitrile $(\bullet)$ and in toluene ( ). Reaction conditions: 2'-aminochalcone (1mmol), 8 wt \% MCM-41(15), $100^{\circ} \mathrm{C}, 0.5 \mathrm{~mL}$ of solvent. 


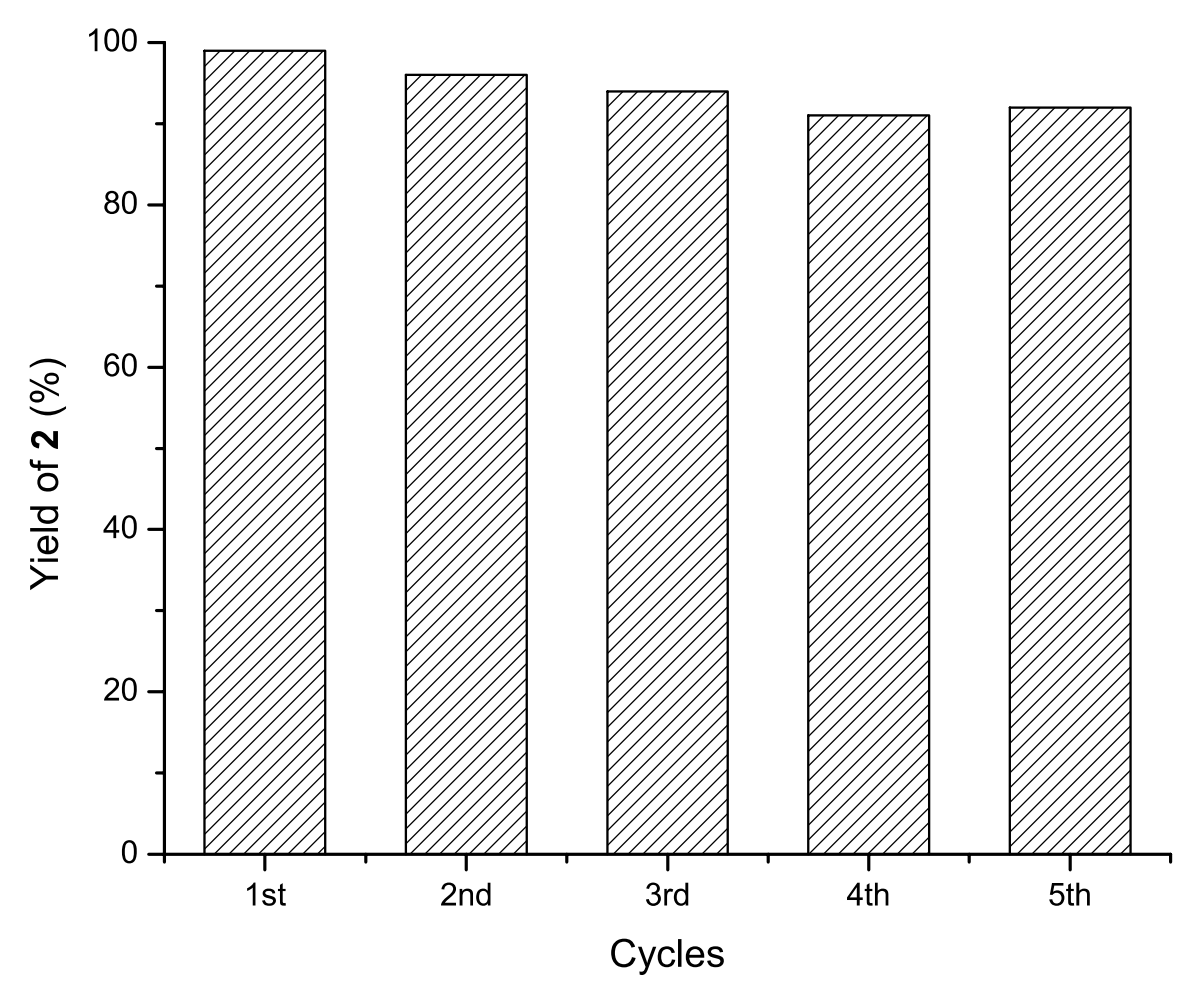

Figure 6. Reusability of MCM-41(15) catalyst in the synthesis of dihydroquinolinone (2). Reaction conditions: 2'-aminochalcone (1mmol), 8 wt \% MCM-41(15), $100 \stackrel{\circ}{\circ}$, $0.5 \mathrm{~mL}$ toluene. 


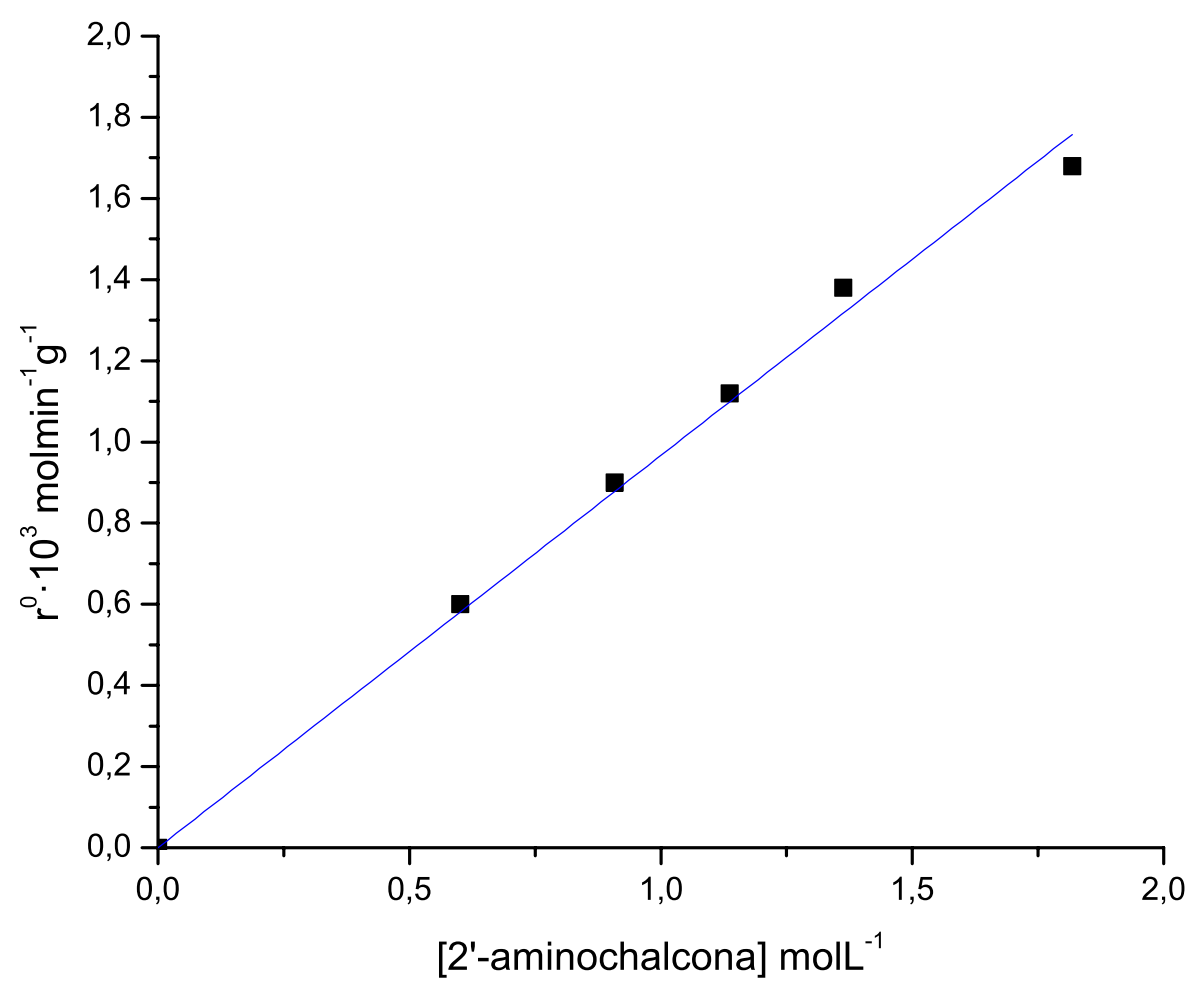

Figure 7. Plot of initial cyclization reaction rate versus different molar concentrations of 2'-aminochalcone. Reaction conditions: initial concentration of 2'-aminochalcone variable between $0.6-2 \mathrm{~mol} \cdot \mathrm{L}^{-1}$, toluene $(0.5 \mathrm{~mL})$, catalyst (32mg), $60{ }^{\circ} \mathrm{C}$. 


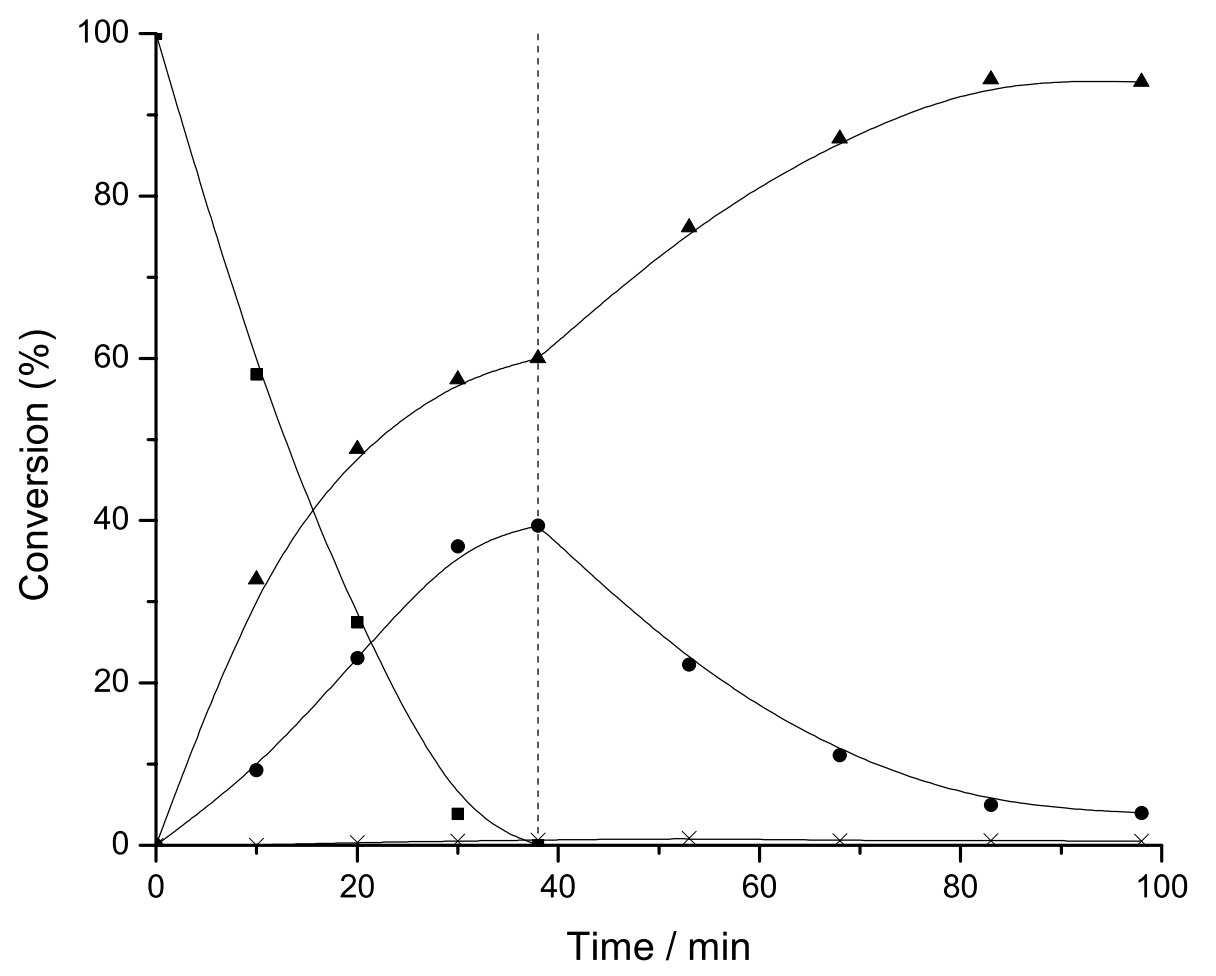

Figure 8. Synthesis of 2-phenyl-2,3-dihydroquinolin-4(1H)-one in one pot process starting from 2'-nitrochalcone. Reaction conditions: 2'-nitrochalcone (0.5mmol), toluene $(0.5 \mathrm{~mL}), 0.2 \% \mathrm{Pt} / \mathrm{TiO}_{2}(15 \mathrm{mg}), \mathrm{MCM}-41(15)(15 \mathrm{mg})$. First step: $70{ }^{\circ} \mathrm{C}, 9$ bar hydrogen pressure. Second step: $100^{\circ} \mathrm{C}, \mathrm{N}_{2}$ atmosphere. 2'nitrochalcone $(\bullet)$, 2'-aminochalcone $(\mathbf{\Delta})$, dihydroquinolinone $(\mathbf{\square}),(\mathrm{X})(1-(2-$ aminophenyl)-3-phenylpropan-1-one. 
Schemes

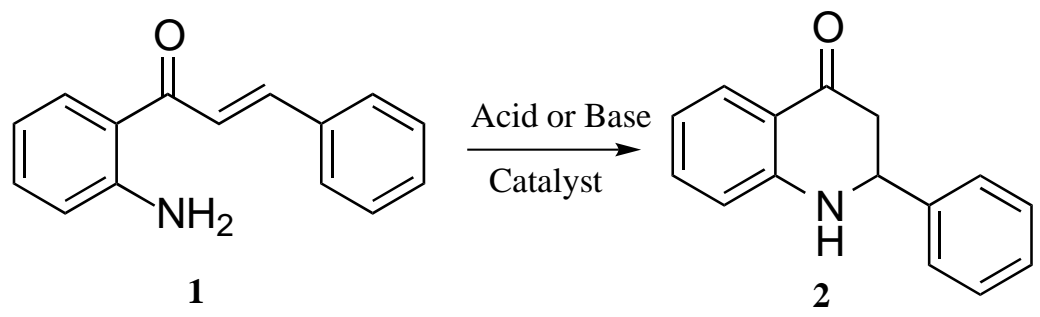

Scheme 1. Synthesis of 2-phenyl-2,3-dihydroquinolin-4(1H)-one (2) from 2'aminochalcone (1). 


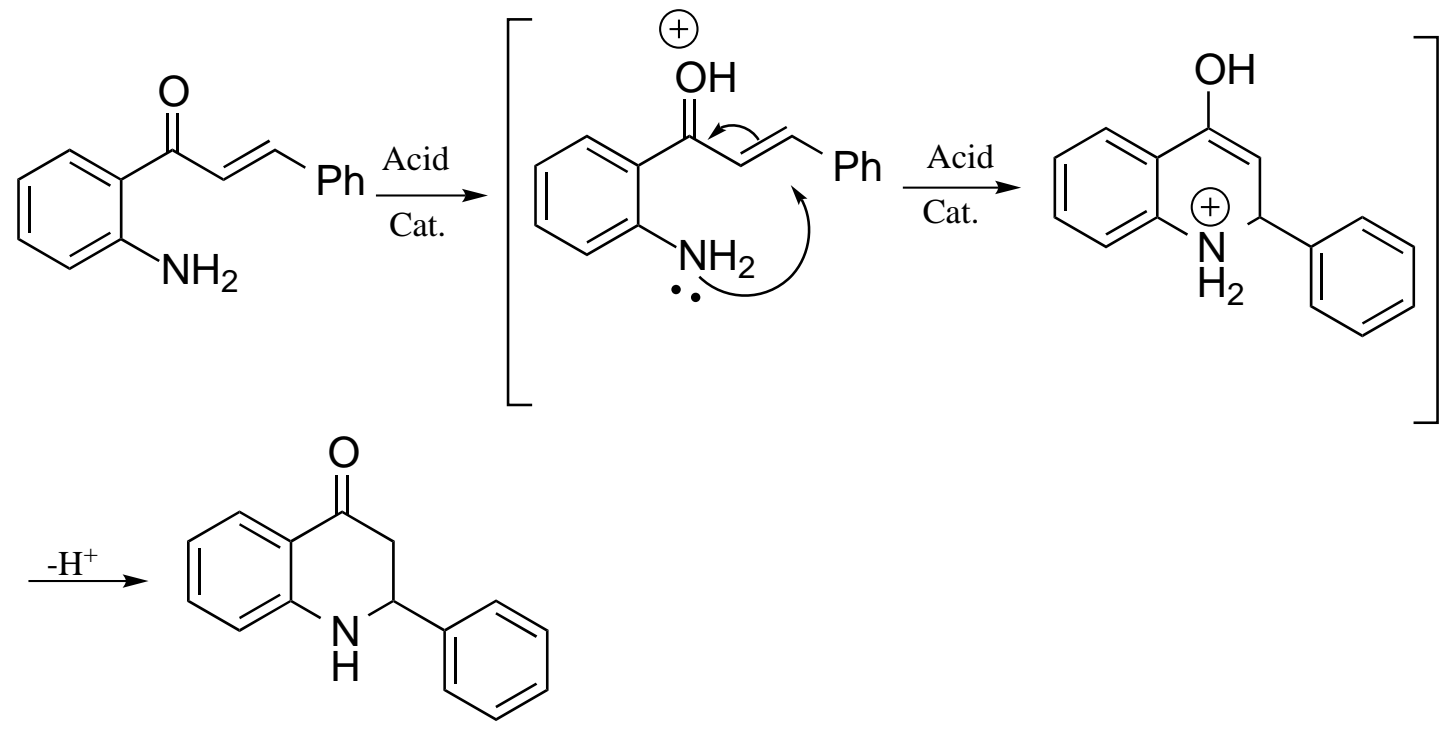

Scheme 2. Intramolecular cyclization mechanism of 2'-aminochalcones in acidic media. 
<smiles>Nc1ccccc1C(=O)/C=C/c1ccccc1/N=C/c1ccc2c(c1)NC(c1ccccc1)CC2=O</smiles>

Scheme 3. One pot process of 2,3-dihydroquinolinone from 2'-nitrochalcone. 
<smiles>CCc1ccc(/C=C/C(=O)c2ccccc2[N+](=O)[O-])cc1</smiles><smiles>O=C1CC(c2ccccc2)Nc2ccccc21</smiles><smiles>Nc1ccccc1C(=O)/C=C/c1ccccc1</smiles><smiles>C/C=C/c1ccccc1/C=C/C(=O)c1ccccc1N=O</smiles>

Scheme 4. Products obtained in the reduction of 2'-nitrochalcones. 


\section{Supporting Information}

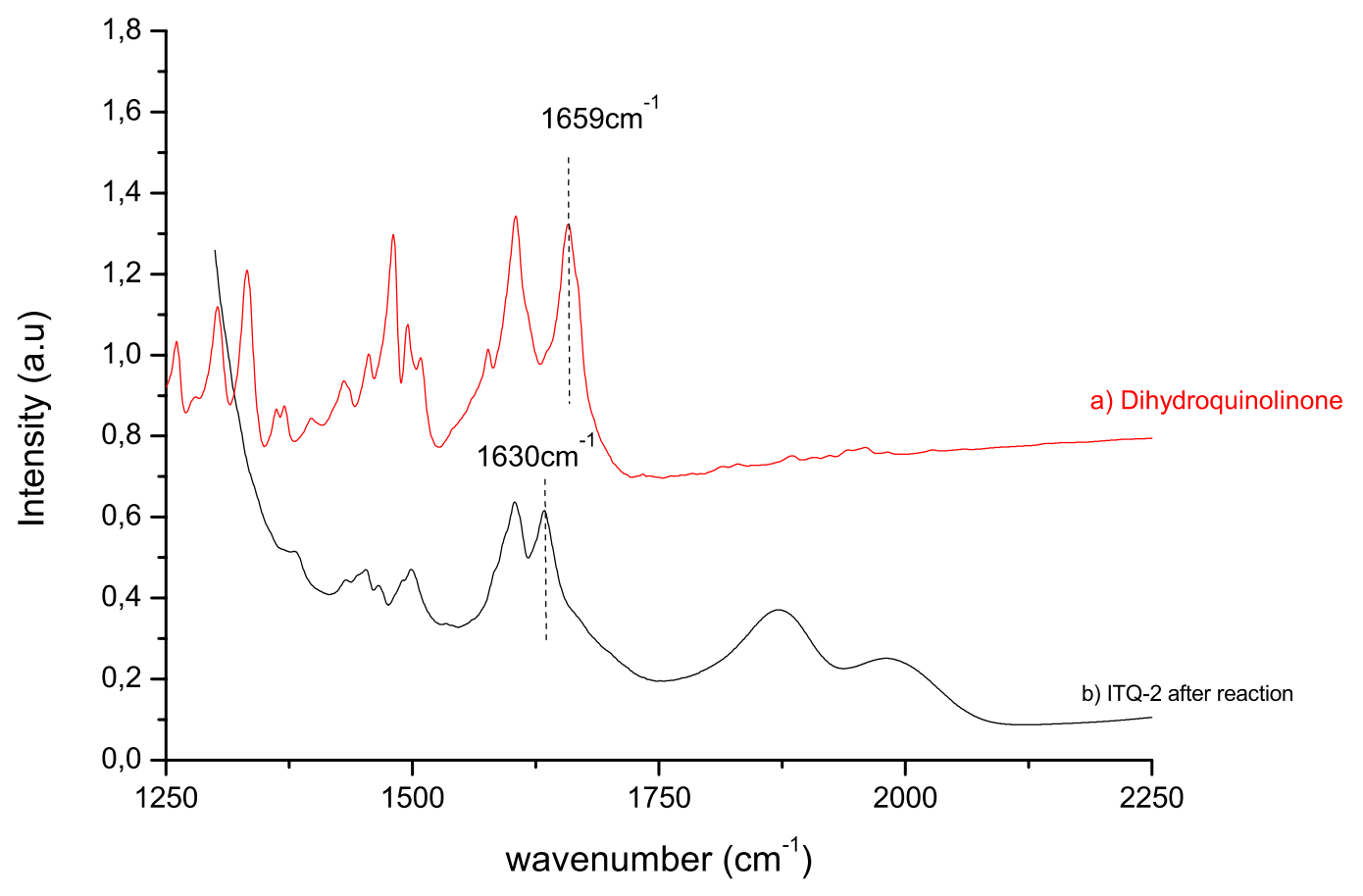

Figure 1SI. a) IR spectrum of pure dihydroquinolinone (2). b) IR spectrum of ITQ-2 catalyst after reaction. 


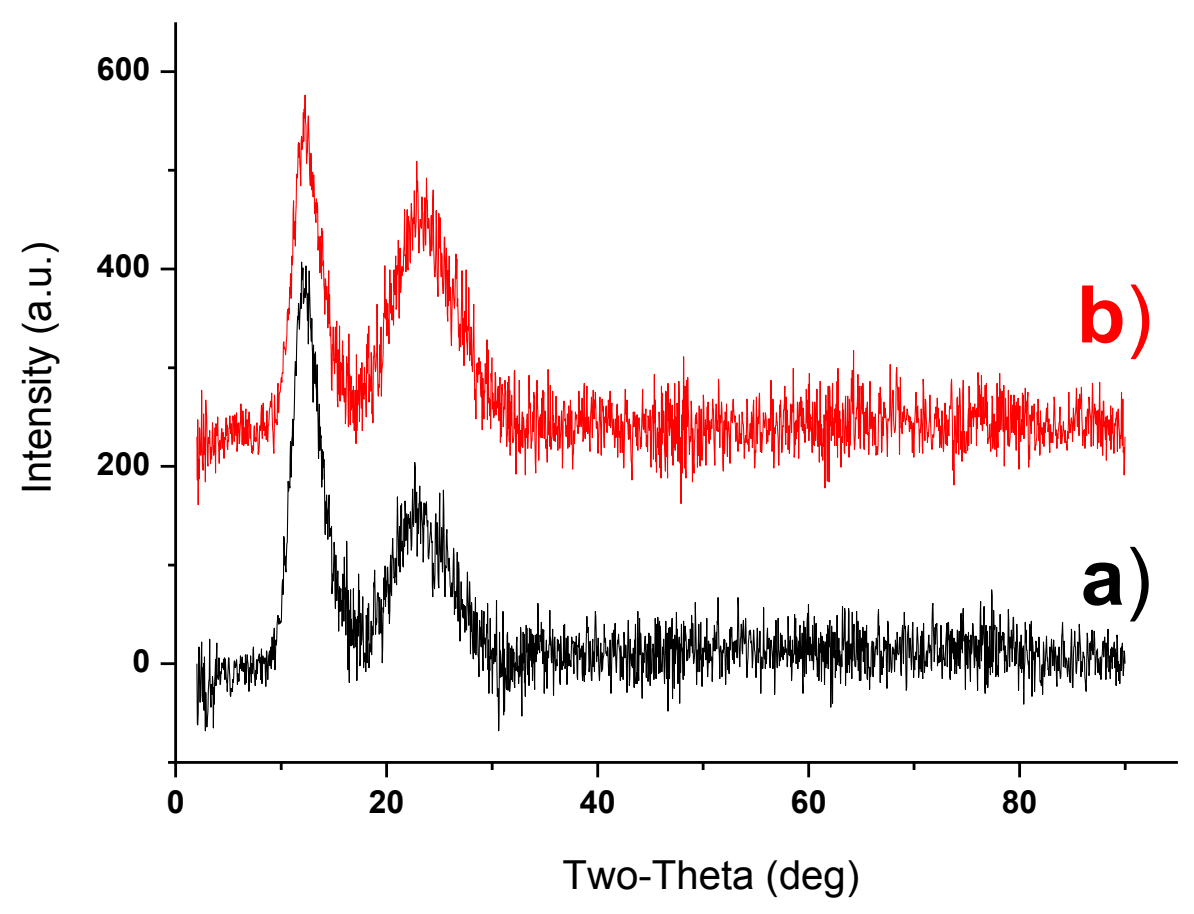

Figure 2SI. XRD patterns of the MCM-41 (15) a) fresh catalysts, b) used catalyst. 


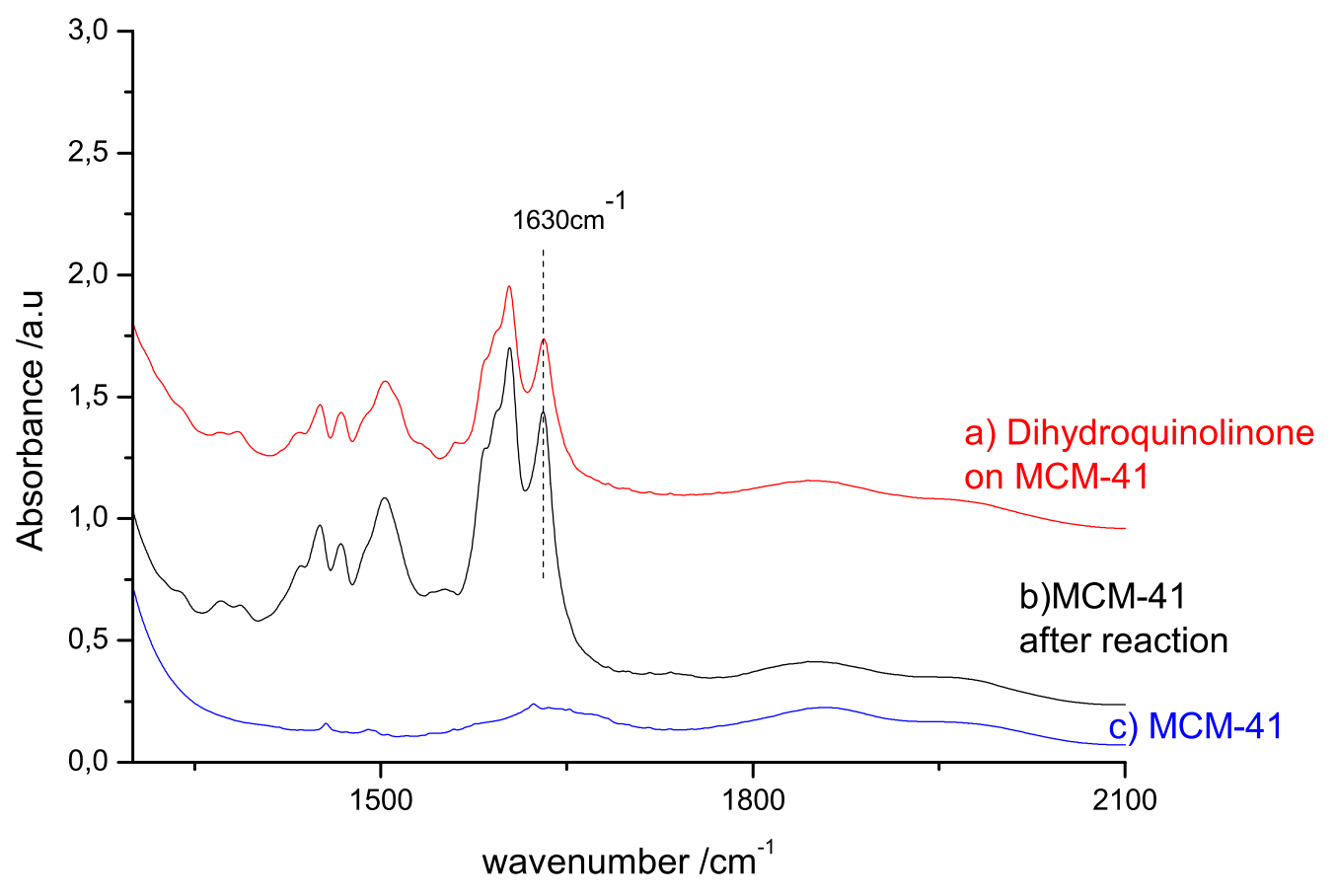

Figure 3SI. a) IR spectrum of pure dihydroquinolinone (2) adsorbed on MCM41(15). b) IR spectrum of the MCM-41(15) after reaction, c) Fresh catalyst 


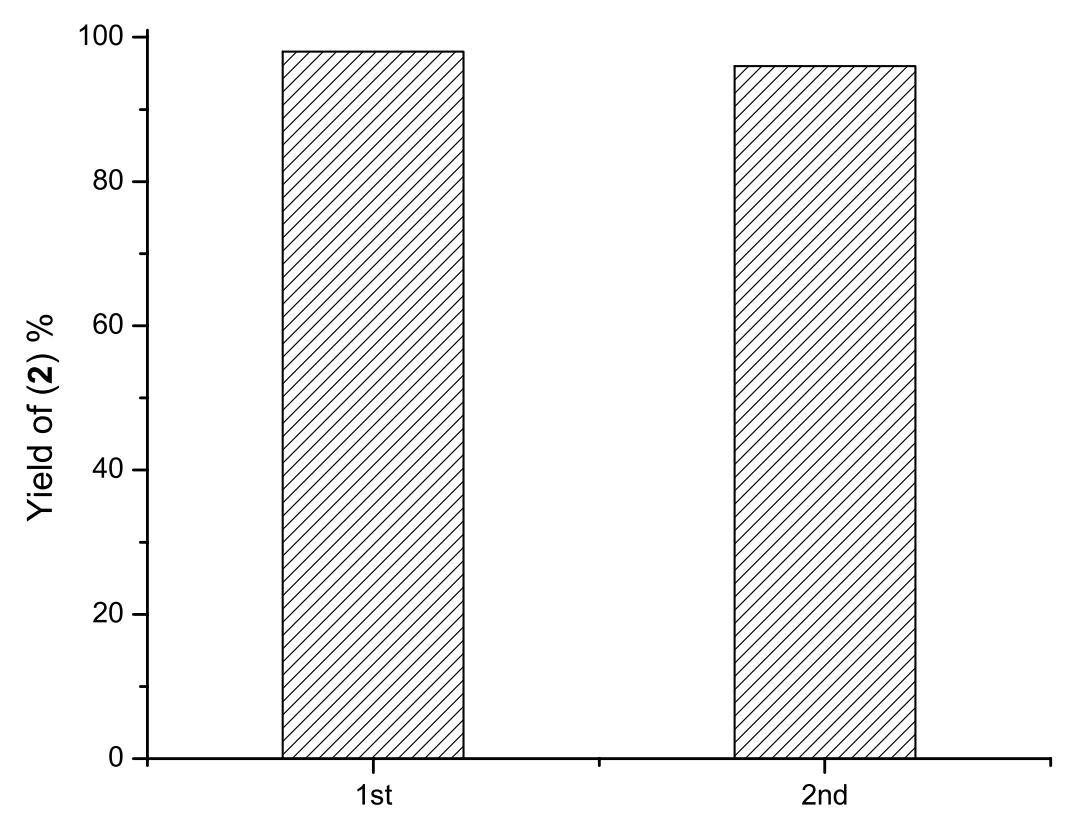

Figure 4SI. Reuse of MCM-41(15) at $150{ }^{\circ} \mathrm{C}$ in acetonitrile as a solvent $\left(1^{\text {st }}\right.$ cycle at $20 \mathrm{~min} ; 2^{\text {nd }}$ cycle at $120 \mathrm{~min}$ ) 


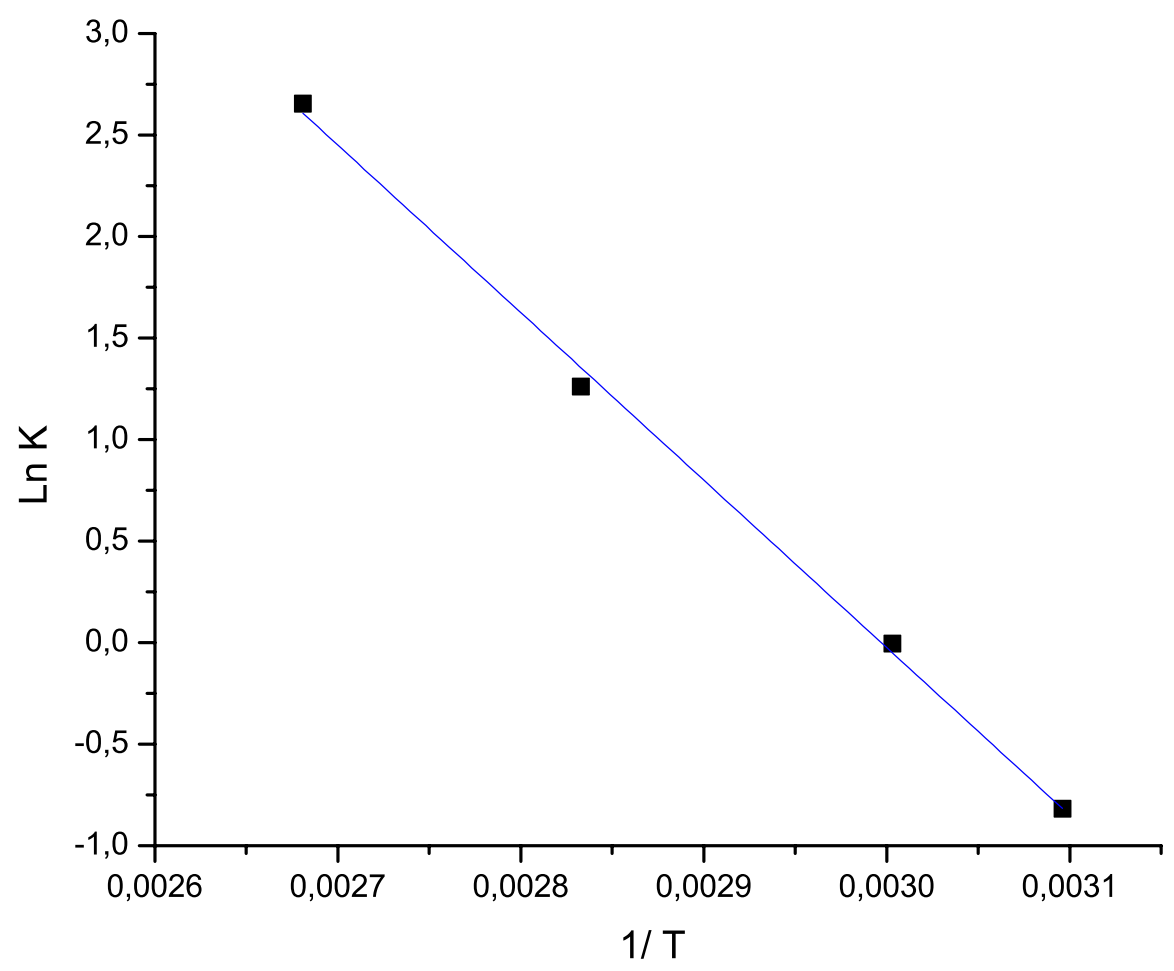

Figure 5SI. Arrhenius plot. Reaction conditions: 2'-aminochalcone (1mmol), MCM-41 (15wt\%), $100 \stackrel{\circ}{\circ}, 0.5 \mathrm{~mL}$ Toluene 